\title{
The "Hidden Diversity" of Medicinal Plants in Northeastern Brazil: Diagnosis and Prospects for Conservation and Biological Prospecting
}

\author{
Deyvson Rodrigues Cavalcanti ${ }^{1,2,3}$ and Ulysses Paulino Albuquerque ${ }^{1}$ \\ ${ }^{1}$ Laboratory of Applied Ethnobotany, Department of Biology, Federal Rural University of Pernambuco, \\ Avenida Dom Manoel de Medeiros s/n, Dois Irmãos, 52171-900 Recife, PE, Brazil \\ ${ }^{2}$ State University of Alagoas, AL $115 \mathrm{Km}$ 3, 57601-000 Palmeira dos Índios, AL, Brazil \\ ${ }^{3}$ Federal Institute of Education, Science and Tecnology of Alagoas, Avenida das Alagoas s/n, Palmeira de Fora, \\ 57601-220 Palmeira dos Índios, AL, Brazil
}

Correspondence should be addressed to Deyvson Rodrigues Cavalcanti; deyvson@yahoo.com and Ulysses Paulino Albuquerque; upa677@hotmail.com

Received 25 April 2013; Accepted 8 June 2013

Academic Editor: Rômulo Romeu Nóbrega Alves

Copyright (C) 2013 D. R. Cavalcanti and U. P. Albuquerque. This is an open access article distributed under the Creative Commons Attribution License, which permits unrestricted use, distribution, and reproduction in any medium, provided the original work is properly cited.

\begin{abstract}
Increases in ethnobotanical studies and knowledge in recent decades have led to a greater and more accurate interpretation of the overall patterns related to the use of medicinal plants, allowing for a clear identification of some ecological and cultural phenomena. "Hidden diversity" of medicinal plants refers in the present study to the existence of several species of medicinal plants known by the same vernacular name in a given region. Although this phenomenon has previously been observed in a localized and sporadic manner, its full dimensions have not yet been established. In the present study, we sought to assess the hidden diversity of medicinal plants in northeastern Brazil based on the ethnospecies catalogued by local studies. The results indicate that there are an average of at least 2.78 different species per cataloged ethnospecies in the region. Phylogenetic proximity and its attendant morphological similarity favor the interchangeable use of these species, resulting in serious ecological and sanitary implications as well as a wide range of options for conservation and bioprospecting.
\end{abstract}

\section{Introduction}

Medicinal plants are freely circulated in Brazil, particularly in informal trade settings where several types of plants are marketed for a wide range of illnesses (see [1]). Limited access to specialty medicine and an increasing interest in the socalled natural treatments account for the rapid increase of the trade in such products in Brazil [2].

The most important vendors of medicinal plants are located in urban centers, namely, in fairs and public markets, where consumers have easy access to a wide variety of medicinal plant species together with the corresponding therapeutic indications [3]. More specifically, the regional public markets act as spaces representative of the cultural production and biological diversity of a given area $[1,4]$ and as centers where the empirical knowledge retained in different areas and with different origins is aggregated, conserved, and spread. Thus, the regional public markets are the pillars of a complex, open, and dynamic system of knowledge [1].

Although promising for the biological prospecting of novel drugs and pharmaceutical products, actual research at such markets has some limitations, as the identity of the vast majority of the plant species traded there cannot be safely established by means of conventional methods $[1,5-7]$.

In contrast with community-based ethnobotanical surveys, where the investigated resources are directly accessible in loco [8-11], research at markets and fairs is much more complex, as a significant proportion of the plant products offered to the consumers are uncharacteristic or lack the elements required for accurate taxonomic identification 
(see $[1,5,6])$. As a rule, only parts of the plants are sold, to wit, the ones allegedly containing the active therapeutic components, such as barks, roots, seeds, flowers, and leaves, which are sometimes dehydrated, chopped, and/or ground. As a result, it becomes quite easy to mix or mistake a similar species with or for another.

Several authors have previously expressed such concerns and proposed some methodological solutions to the problem $[1,12]$. Various palliative techniques have been suggested for cataloging all medicinal plants available to the consumers at public markets, some of which are quite specialized and expensive [13-15], whereas others are feasible but not always viable $[16,17]$.

In addition to morphological similarities between species, another factor that makes it difficult to interpret the ethnobotanical data collected at public markets is the fact that multiple plants species are frequently known by the same vernacular name. Such events of semantic correspondence in ethnobotanical studies were initially detected by several authors [18-21] and then properly systematized by Berlin [22] in a study that sought to determine the relationships between the biological and traditional classification systems, thus establishing the grounds of ethnotaxonomy.

Within that ethnotaxonomic approach, Berlin [22, 23] established the notion of underdifferentiation to define the semantic correspondence between different species that share a vernacular name, of which two types were described. Underdifferentiation type 1 occurs when the species involved belong to the same genus, and type 2 occurs when they belong to different genera. When only one species corresponds to a given ethnospecies, correspondence is defined as one-to-one or biunivocal $[22,23]$. Several studies of local communities have employed these notions to identify similar patterns of semantic correspondence between different species [2428]. The species subjected to underdifferentiation have been termed ethnohomonyms.

Although quite well adjusted to the local systems, such correspondences tend to overlap and become complex when different cultural origins become somehow intertwined [29, 30]. The overlapping of homonym ethnospecies makes the understanding of ethnobotanical data originating in environments where complex cultural networks are established even more difficult, as is the case with ethnobotanical studies at regional public markets (see [6]).

We define here the "hidden diversity" of medicinal plants as the set of different homonym ethnospecies "hidden" under the same vernacular name. We coined the term "hidden diversity" based on the analogy with the notion of a "hidden harvest," which denotes the progressive and unofficially documented appropriation of the plant biodiversity in a given area $[31,32]$.

According to Krog et al. [6] the impossibility of distinguishing among homonym ethnospecies is one of the major limitations to the advancement of ethnobotanical research in public markets, particularly in the case of ethnopharmacological studies of plant conservation and bioprospection. Although that phenomenon has previously been detected in a localized and sporadic manner, its full dimensions have not yet been established.
It is safe to assume that in Brazil, as a function of the plant biodiversity, environmental diversity, and multicultural and ethnic composition of the country [33], the number of homonym ethnospecies and consequently also the phenomenon of hidden diversity of medicinal plants is much more comprehensive and significant than suggested from the few occurrences recorded in the scientific literature. In the present study, we sought (1) to measure the hidden diversity, that is, the number of medicinal plant species subsumed under the same common name in the Brazilian northeast region; (2) to establish the different types of underdifferentiation of homonym ethnospecies; and (3) to assess the influence of biological diversity on the number of homonym ethnospecies. Finally, we sought to indicate some of the possible implications for conservation and biological prospecting.

Assuming that the variety of homonym ethnospecies in a given region depends on the region's biodiversity, one might expect the following: (1) for the variation in the number of homonym ethnospecies to be directly proportional to the size of the sampled area, as larger areas theoretically include a wider variety of environments, and consequently, also greater biological diversity and (2) that a significant number of the homonym ethnospecies should be representative of the native flora compared to the group of species with one-to-one correspondence.

\section{Materials and Methods}

2.1. Characterization of the Study Area. The northeast region of Brazil includes nine federal units and represents a total area of $1,558,196 \mathrm{~km}^{2}$, which corresponds to $18 \%$ of the country's territory. It is located in an intertropical zone limited by the Atlantic Ocean to the east and north, the Amazonian rainforest to the northwest, and the Cerrado (Brazilian savannah) domain to the west and southwest [34]. The vegetation is mainly xerophytic, being the Caatinga (Brazilian xeric shrubland), a highly peculiar biome with a high degree of endemism [35-37]. Atlantic ombrophilous forest predominates in the coastal area. Currently, this forest is one of the most seriously threatened biomes in the world, and only $5 \%$ of its original area remains [38, 39]. Enclaves of Cerrado and rainforest are widely present as areas of disjunct vegetation [40-43], making the Brazilian northeast region a strategic area from the perspective of global richness and biological diversity $[44,45]$.

From the demographic point of view, the total population of the northeast region comprises approximately 49 million inhabitants, primarily distributed along the coastal area where most state capitals and major cities are located, which together host approximately $40 \%$ of the population [34]. The cultural diversity of the northeast region is high due to the ethnic miscegenation resulting from the colonization of Brazil $[46,47]$, and the population includes Europeans, mostly Portuguese and Dutch, black slaves from Africa, and the various indigenous peoples. In addition, it is worth observing that in the last ten years, the economic growth of the region was significantly higher than the national average [34]. 
2.2. Data Survey. Six of the nine northeastern states were included in the analysis based on the need to survey the widest possible diversity of cultural representations and environments and the need to take into account the logistics of access and permanence at the study sites. For the purposes of the present study, we assumed that the expression of the regional culture is more diversified at the state capitals because they exhibit the largest population density, including immigrants from other states and/or the inland cities.

The states and corresponding capitals sampled were as follows: Maranhão/São Luiz, Ceará/Fortaleza, Paraíba/João Pessoa, Pernambuco/Recife, Alagoas/Maceió, and Sergipe/ Aracaju. The primary site of medicinal plant trade in each state capital was identified, and thus the following markets were selected: the Mercado Central (Central Market) in São Luiz/MA, Mercado de São Sebastião (St. Sebastian Market) in Fortaleza/CE, Mercado Central in João Pessoa/PB, Mercado São José (St. Joseph Market) in Recife/PE, Mercado da Produção (Production Market) in Maceió/AL, and Mercado Albano Franco (Albano Franco Market) in Aracaju/SE.

Following an initial exploratory visit, an appointment was made for data collection. The plant vendors at each selected market were informed as to the nature of the study and invited to participate. Some vendors refused immediately, and others initially agreed and then went back on their original agreement. As a result, a total of 22 respondents were interviewed and provided a representative sample of the vernacular names of the plants traded in the region. In the state of Pernambuco, the ethnobotanical studies in public markets are already more advanced. Albuquerque and colleagues [1] previously found a significant decrease in the availability of plant vendors in this state based on only two samples obtained over an eightyear period. The in situ observations and data collected for the present study suggest that this decrease in availability may represent a general trend that can be explained by several factors. For instance, the lack of regulation and control of the sector in regards to health and ecological aspects may generate mistrust and insecurity among vendors. The vendors may also experience a lack of return research or "benefits" that would otherwise entice them to be informants. In addition, the harsh economic conditions of the country have removed a significant number of vendors from the market, and unrelenting derogatory campaigns have undermined the informal trade markets in the media. Vendors in the informal trade markets also experience increasing competition with food stores, which are common in large urban centers and usually have better infrastructure, availability, and sanitary conditions. There is also a lack of interest in new generations to continue the family traditions of using and trading medicinal plants.

After the study was explained, the respondents freely signed an informed consent form. The study was approved by the Research Ethics Committee of the Federal University of Pernambuco (Universidade Federal de Pernambuco-UFPE) no. 0039.0.172.0000-10, FR (Folha de Rosto-Title Page) 3139660 .

Although some authors [1] have reported that several terms are used to describe vendors of medicinal plants, eventually including hierarchical criteria, in the present study, we used the generic term "herbalist" (locally known as "erveiro") to allude to any type of vendor of medicinal plants. The term ethnospecies is used in the present study to allude to the common or vernacular names given to the medicinal plants.

Using a field notebook, we made records of the catalogs of plants traded by the herbalists as mentioned in semistructured interviews [48]. For the purposes of the study, the plants available in stock at the time of the study as well as those traded in the previous 12 months were taken into consideration. The common names of the plants were recorded as spelled by the respondents.

2.3. Data Analysis. The ethnobotanical data supplied by the herbalists in the various studied northeastern states were transcribed and entered in digital spreadsheets using MS Excel 2003 software, thus creating a Market Relational Database (MRD). The MRD was used to map the geographical distributions of the ethnospecies across the Brazilian northeast region and identify the most frequently occurring ones.

In parallel, an Ethnobotanical Survey Database (ESD) was created and populated. For that purpose, 55 ethnobotanical surveys of the northeastern states were identified, and the listed species and ethnospecies were entered in the ESD. The plants not identified at the species level were not included. Only relevant studies were selected: most (45) were published in major scientific journals, seven were Master's dissertations, one was a doctoral thesis, one a book, and one the Development Plan of a major Brazilian university (Federal University of Bahia-Universidade Federal da Bahia, UFBA).

The data entered in both databases (MRD and ESD) were then crosschecked to produce a detailed list of the ethnospecies mentioned both in the ethnobotanical surveys and by the respondents in our study, with the corresponding species. This step allowed for the identification of the homonym species and their clustering around the corresponding ethnospecies.

We selected a sample corresponding to $40 \%$ of the ethnospecies included in both databases (MRD and ESD) based on their frequency in the ethnobotanical surveys. Thus, only the 165 most frequent ethnospecies out of a total of 406 listed in the ethnobotanical surveys were selected for analysis.

The sampling criteria used were based on two assumptions: (1) ethnobotanical research is still incipient in most of the northeast region, and thus, infrequent ethnospecies might suggest a merely temporary pattern of semantic correspondence, consequently masking the results, the number of one-to-one correspondences in particular and (2) the ethnospecies most frequently mentioned in the regional ethnobotanical surveys might represent the patterns of semantic correspondence in a more unequivocal and reliable manner.

The corresponding species were allocated to three groups: one comprised the species with one-to-one correspondences, the second, the homonym ethnospecies with type 1 underdifferentiation, and the third, the homonym ethnospecies with type 2 underdifferentiation, according to Berlin's [23] classification. The corresponding species were subjected to synonym analysis; the names that are currently valid were duly recorded based on the List of Species of the Brazilian 
Flora 2012 [49] and the database of the Missouri Botanical Garden [50], which were also used to establish the biogeographic status of each species to classify them as native or exotic.

To assess whether underdifferentiation (sensu Berlin [23]), expressed as the number of homonym ethnospecies, varies as a function of the biological diversity of a given area, we compared the results corresponding to the northeast region with a geographically narrower sample, based on the assumption that the larger the area, the wider the environmental variety, and thus, the more diversified the flora.

That narrower sample was represented by the state of Pernambuco, which is the northeastern state most thoroughly studied from an ethnobotanical perspective. The numbers of homonym ethnospecies and one-to-one correspondences of the northeast region were compared to those of Pernambuco. The frequency of species in the respective categories of semantic correspondence (i.e., one-to-one and underdifferentiation) was analyzed by means of $G$ tests [51] as were the percentages of native and exotic species in each group.

\section{Results}

The ethnospecies $(n=165)$ sampled based on the data collected at the visited markets exhibited correspondence with 459 species, corresponding to 228 genera and 90 families (Table 1). The ratio of species to ethnospecies was 2.78 . From the total number of analyzed ethnospecies, only $41(25 \%)$ exhibited one-to-one correspondence, whereas 124 (75\%) exhibited underdifferentiation and correspondence to 418 species. Approximately $62 \%$ of the homonym ethnospecies exhibited two or three corresponding species, although in some cases, a single ethnospecies included up to nine corresponding homonym species, as, for example, "quebra-pedra" (stonebreaker) (Table 1).

Analysis of the data corresponding to the state of Pernambuco alone identified 138 out of the 165 ethnospecies found in the northeast region, which exhibited correspondence with 203 species. The ratio of species to ethnospecies was 1.46. The pattern of correspondence included 89 (64\%) instances of one-to-one correspondence and 49 (36\%) of underdifferentiation; the homonym ethnospecies represented a total of 114 species.

Comparison of the data from the state of Pernambuco and the northeast region showed variation in the number of one-to-one correspondences that was inversely proportional to the size of the sampled area, whereas the number of homonym ethnospecies varied in proportion to the size of the sampled area, as shown in Figure 1. Consequently, the homonym ethnospecies predominated in the northeast (NE) sample $(G=48.41$; $\mathrm{df}=1 ; P<0.00001)$.

In the group of homonym ethnospecies, 309 (74\%) were representative of the native flora, and 109 (26\%) were exotic species. In the group of ethnospecies with one-toone correspondence, $15(37 \%)$ were representative of the native flora and 26 (63\%) were exotic species (Figure 2). The proportion of native species relative to the proportion of exotic species was therefore significantly greater for the

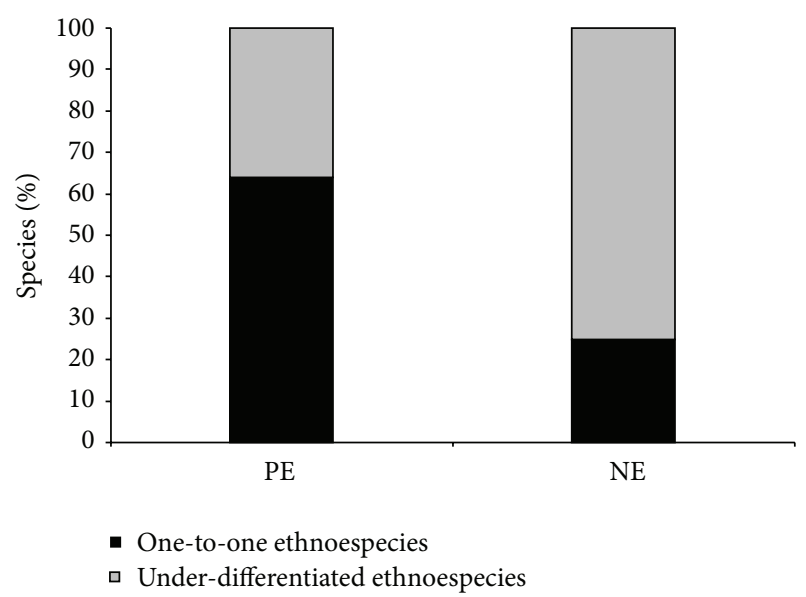

FIGURE 1: Percentages of ethnospecies that exhibited one-to-one correspondence and underdifferentiation marketing in the northeast region and the state of Pernambuco, Brazil.

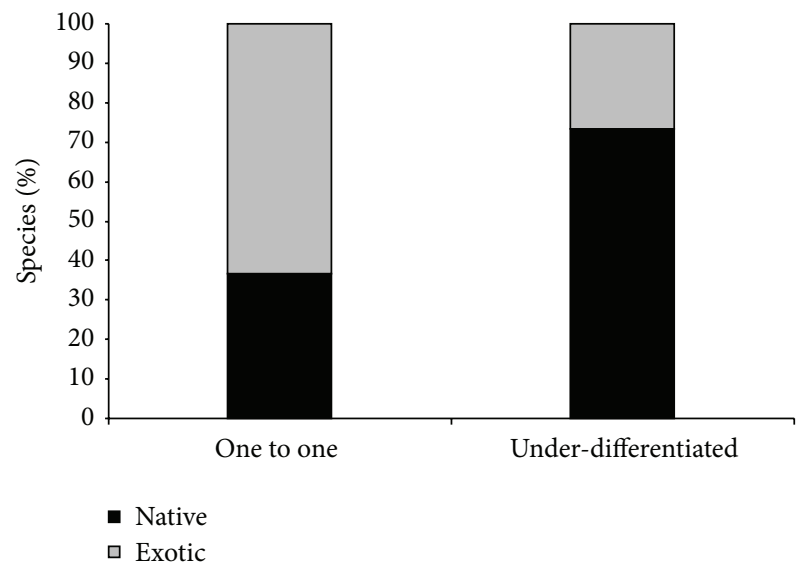

Figure 2: Percentages of native and exotic species in the group of ethnospecies that exhibited one-to-one correspondence and underdifferentiation marketing in the northeast region and the state of Pernambuco, Brazil.

under-differentiated ethnospecies compared to the one-toone ethnospecies ( $G=22.52$; $\mathrm{df}=1 ; P<0.00001)$.

Among the 418 homonym ethnospecies, 256 (61.3\%) were congeneric (type 1 underdifferentiation), and 77 (18.4\%) exhibited correspondence at the genus level only (type 2 underdifferentiation). That is to say, $61 \%$ of the species bear correspondence to at least one other species of the same genus with the same vernacular name, whereas $18.4 \%$ of the homonym ethnospecies exhibited correspondence with one or more species belonging to other genera in the same family. In some cases $(20.3 \%)$, the homonym ethnospecies belonged to different families, such as the ethnospecies "fedegoso" (coffee senna) and "capeba" (cow-foot leaf) (Table 1).

\section{Discussion}

4.1. Hidden Diversity in Regional Markets. Knowledge of the hidden diversity of medicinal plant species represents an 


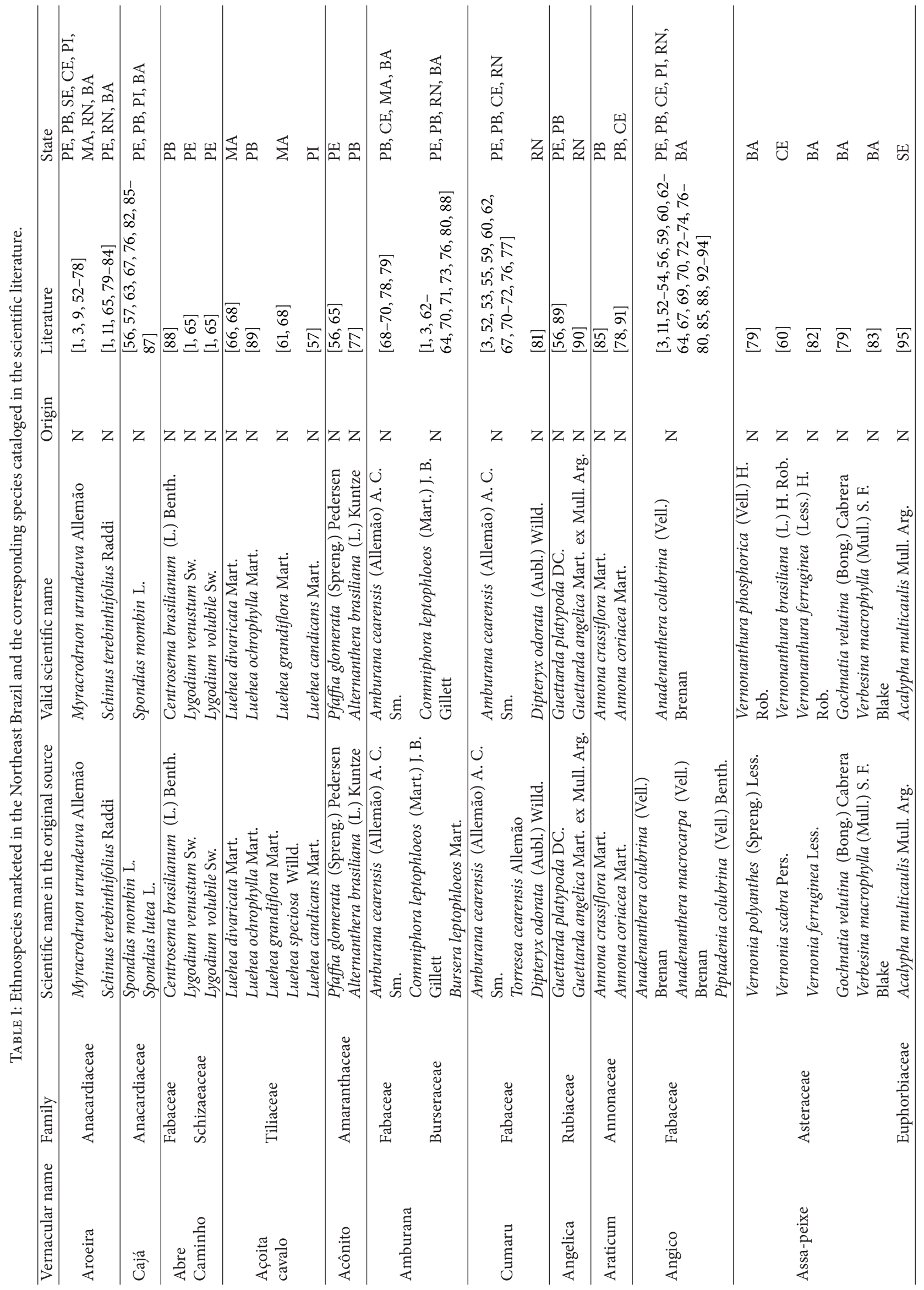




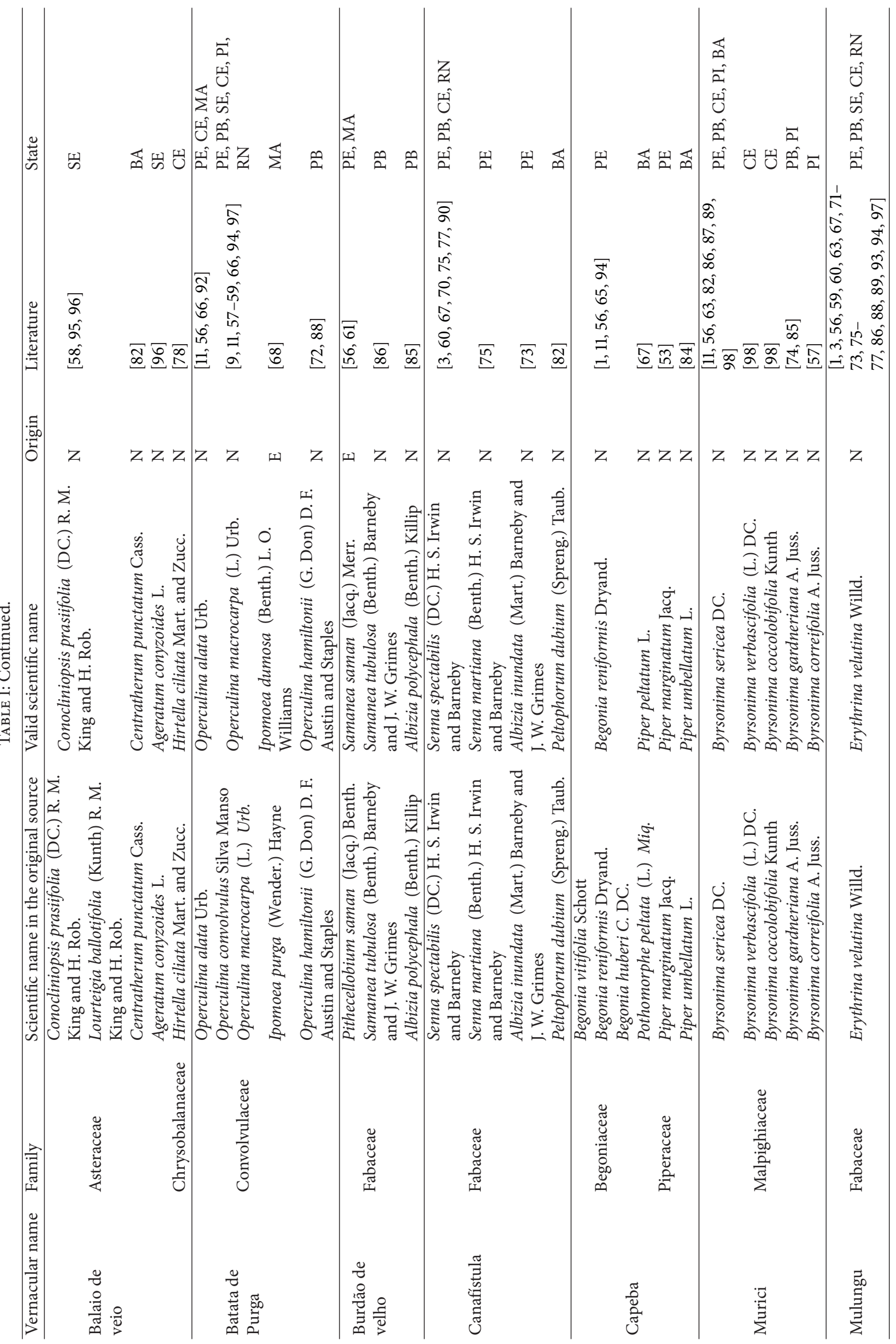




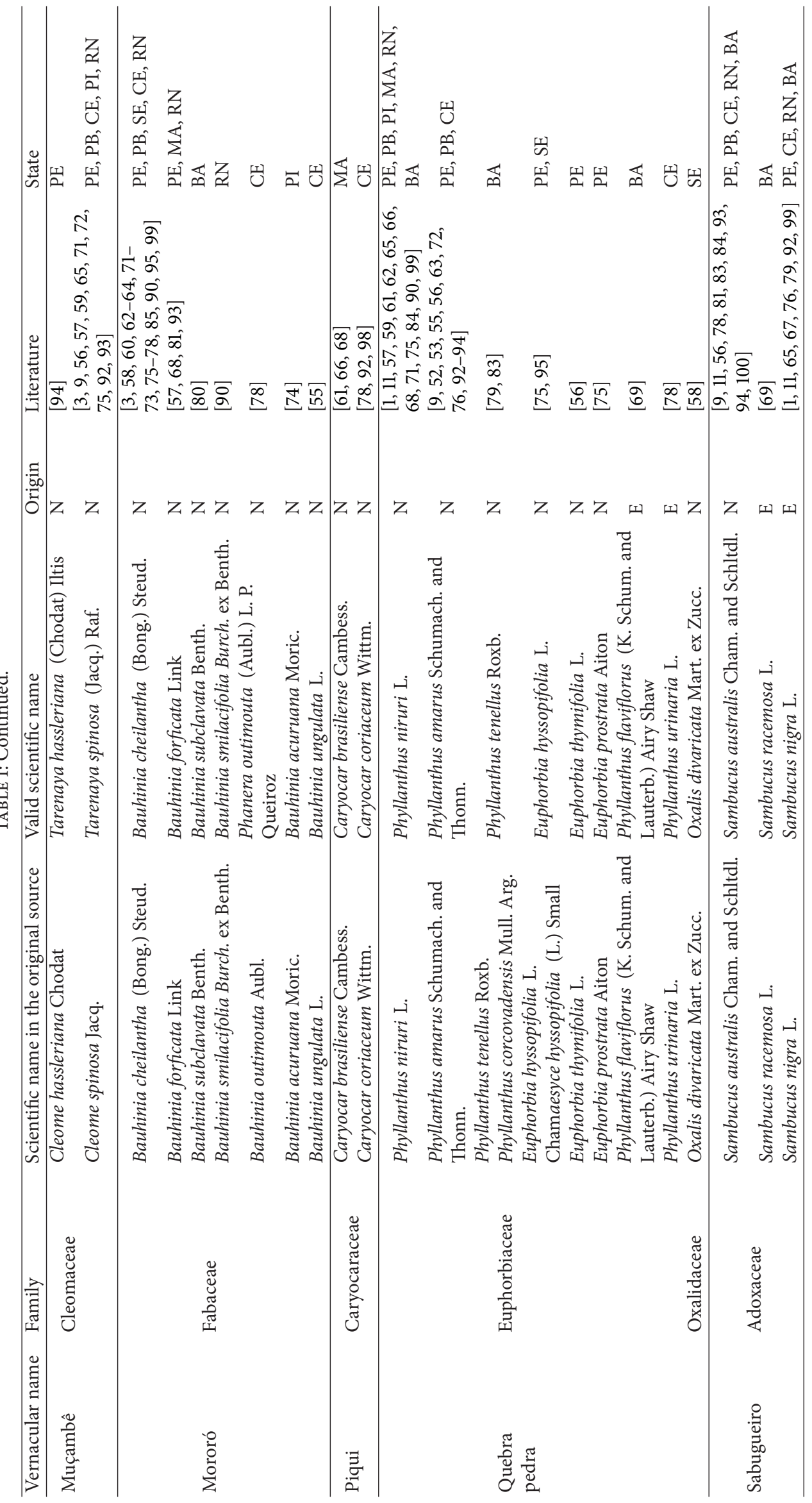




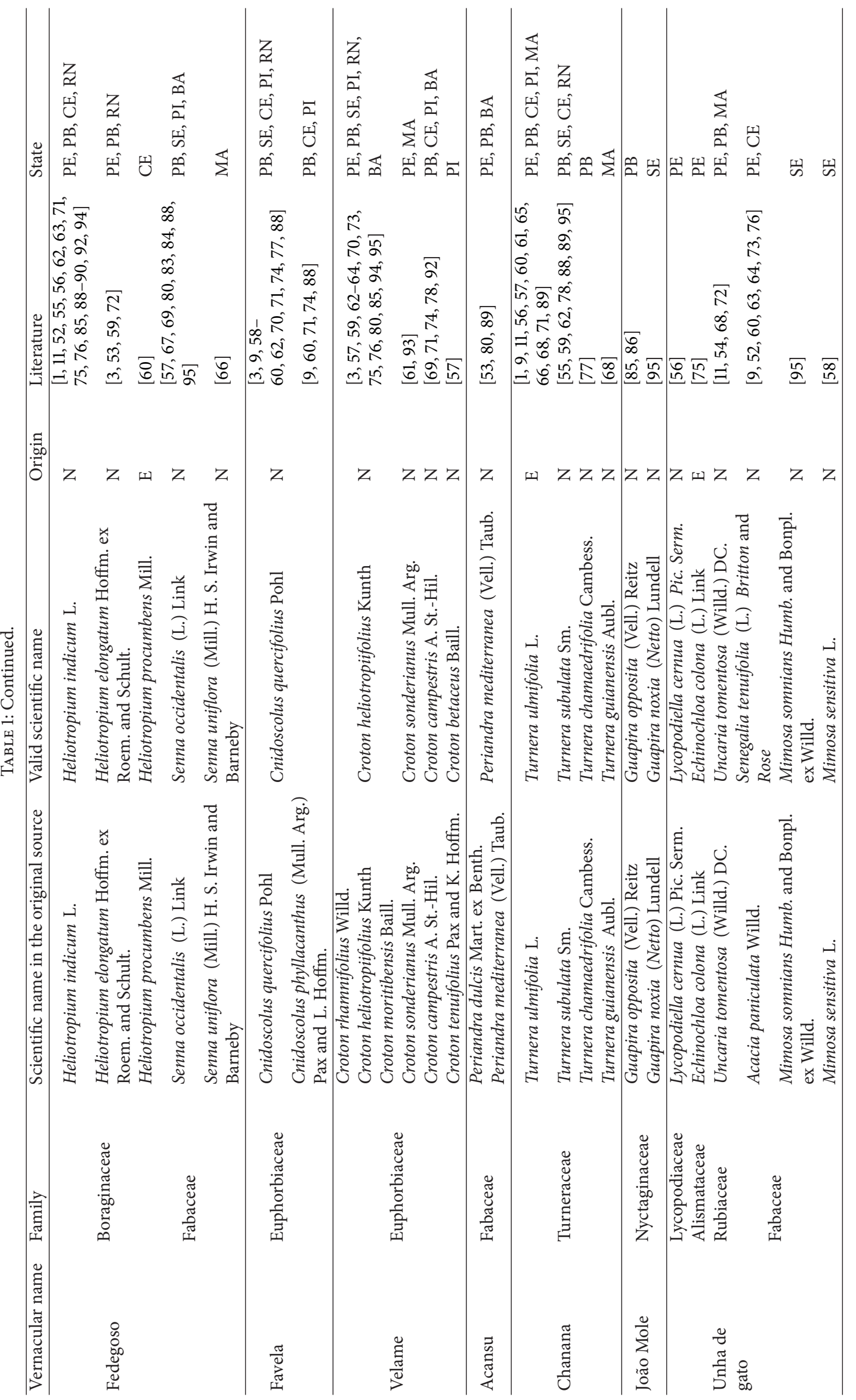




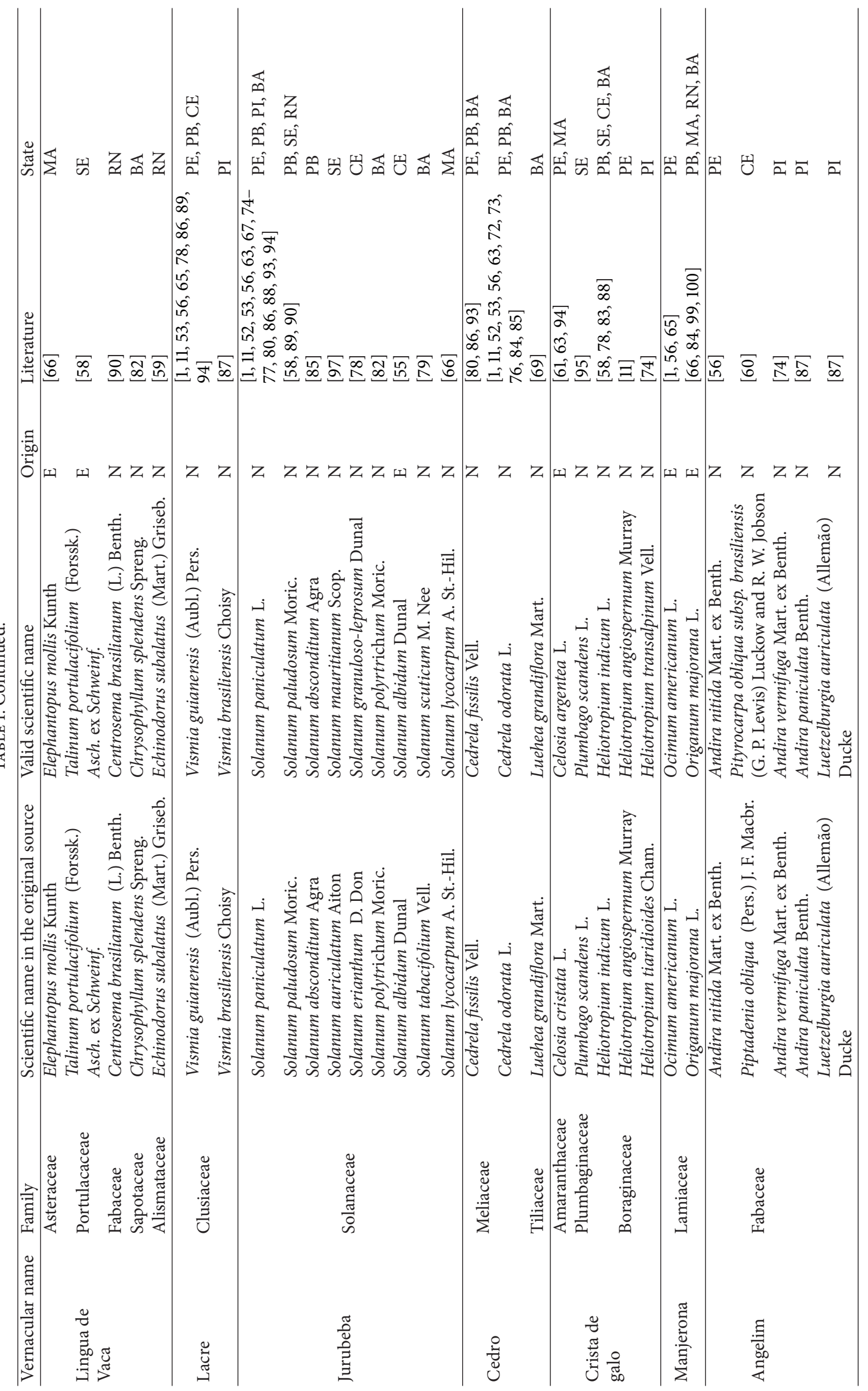




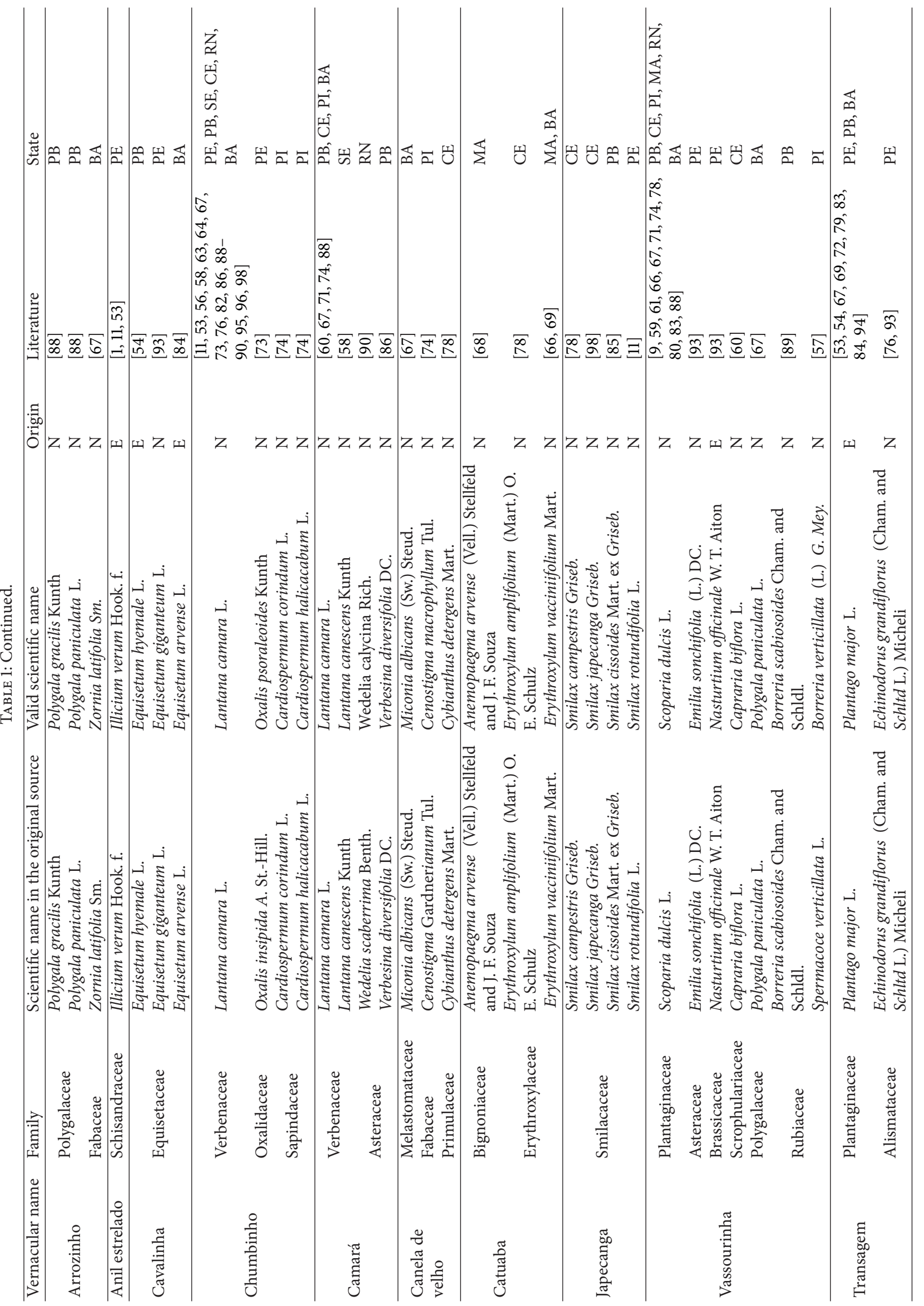




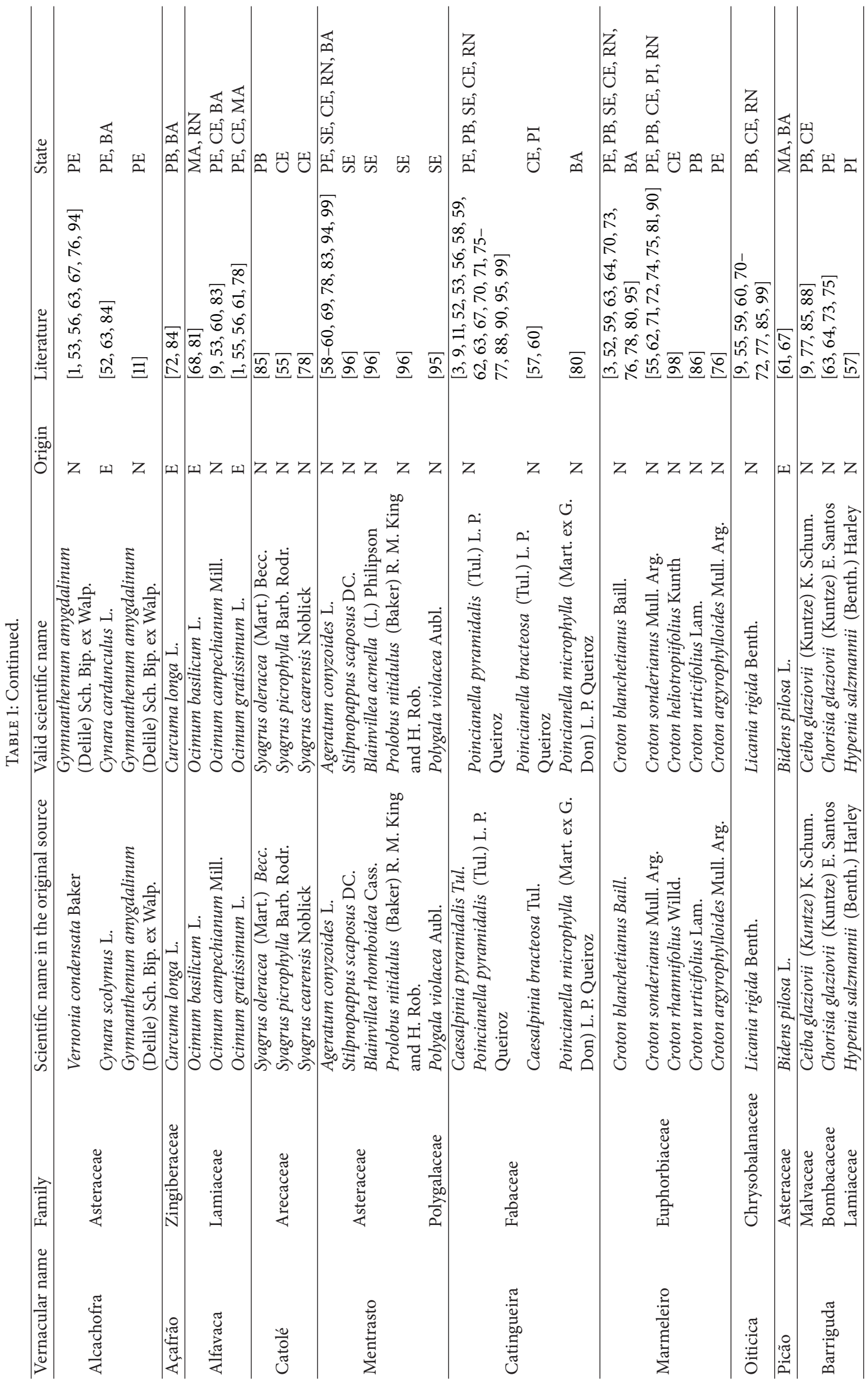




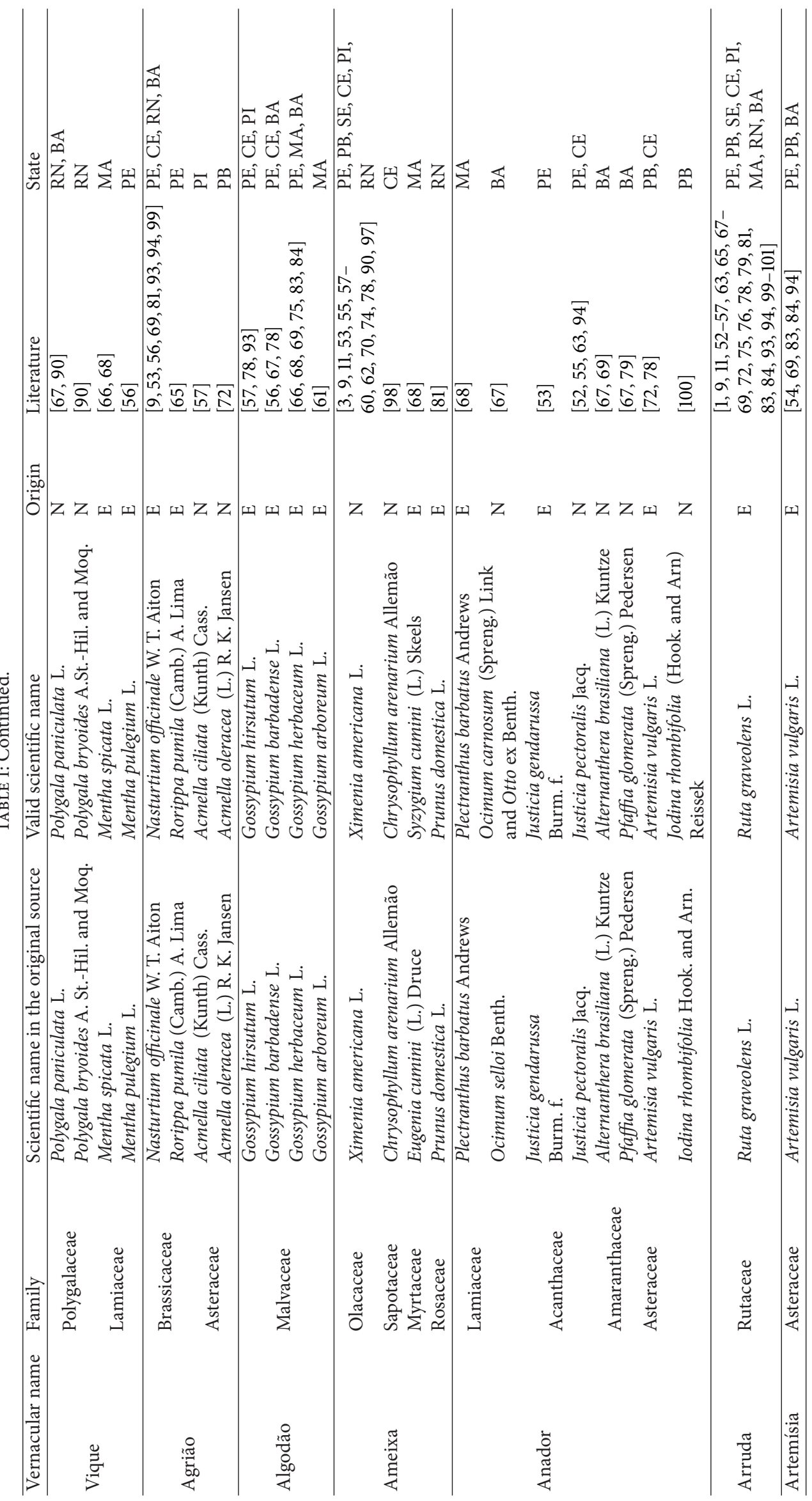




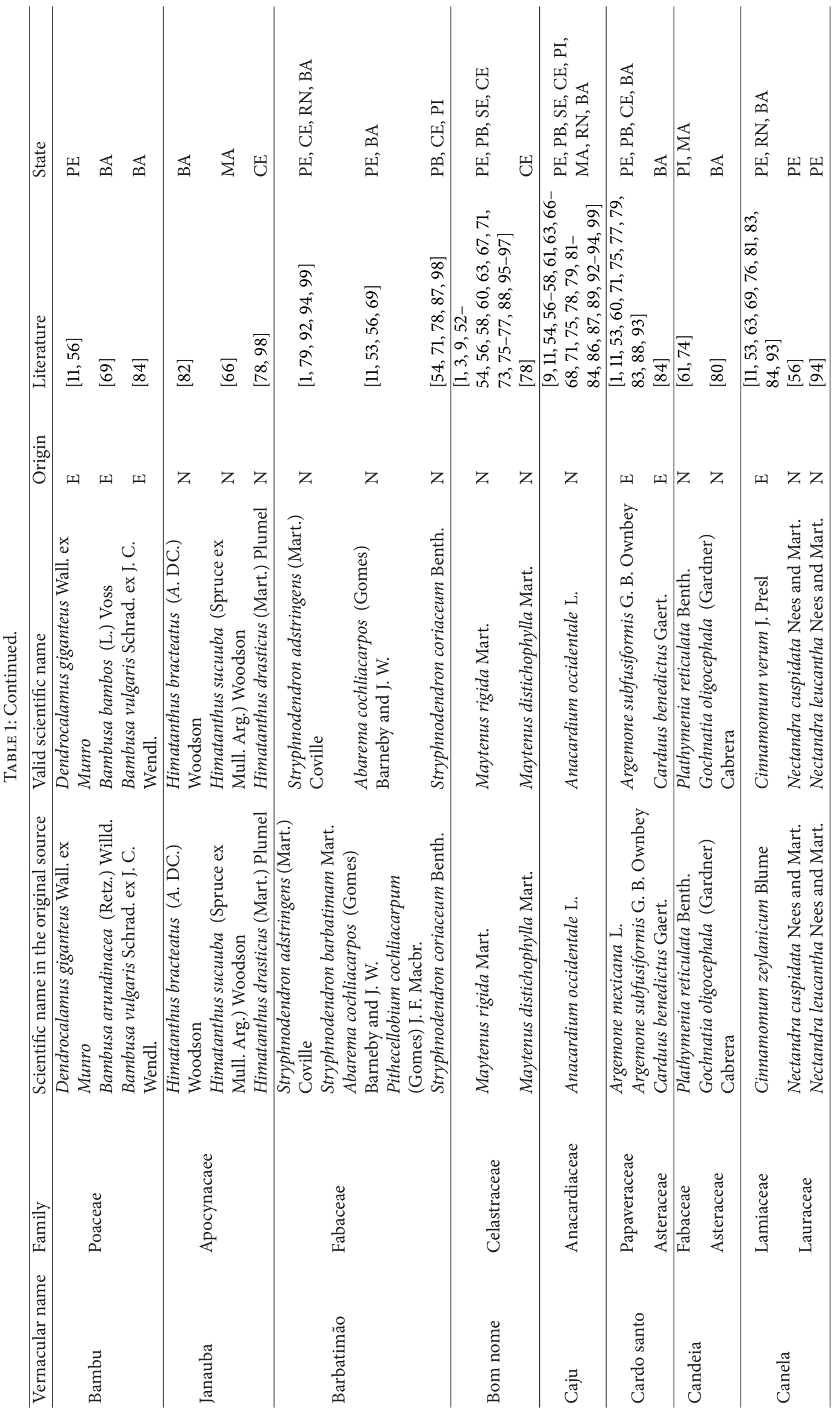




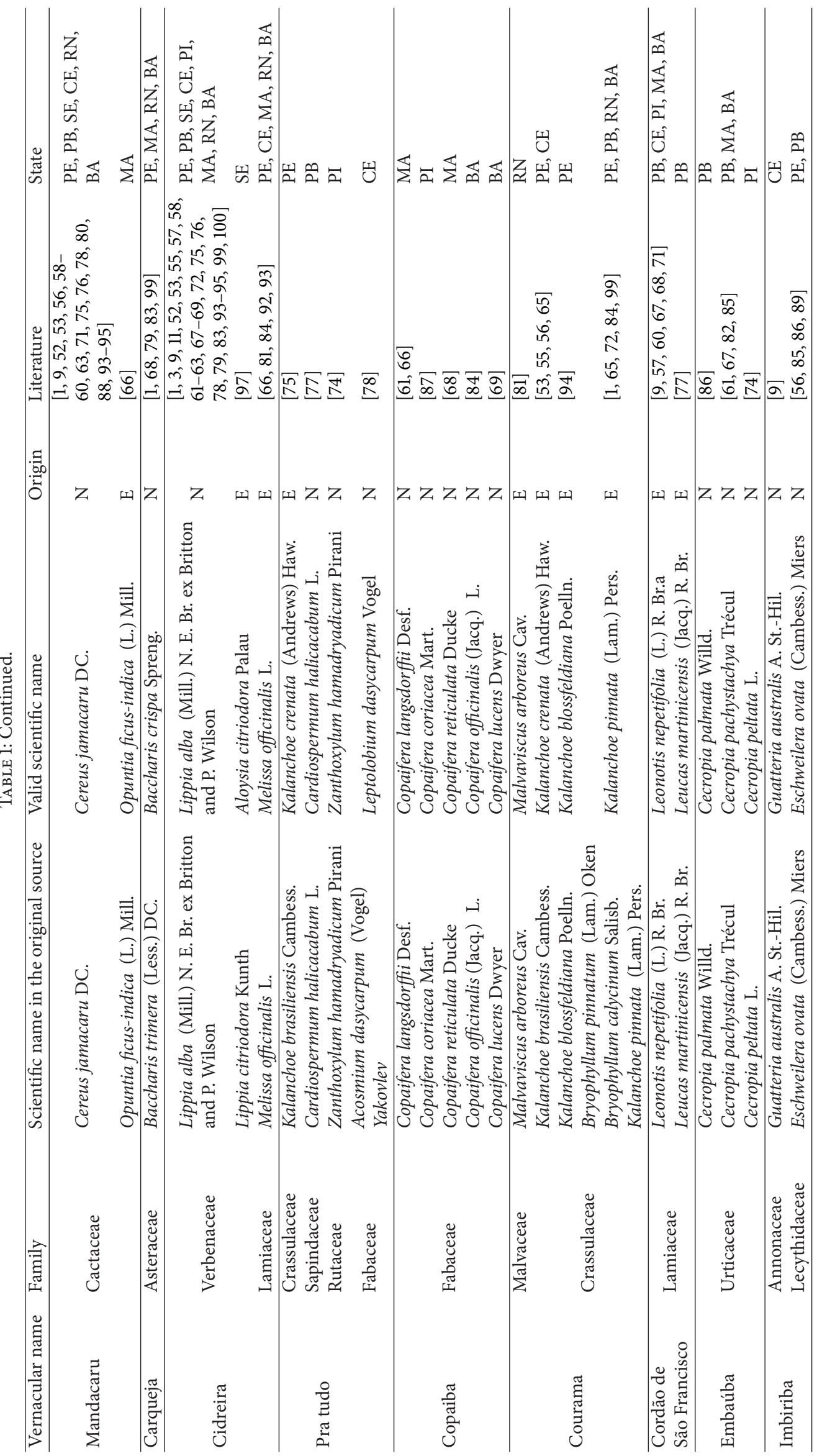




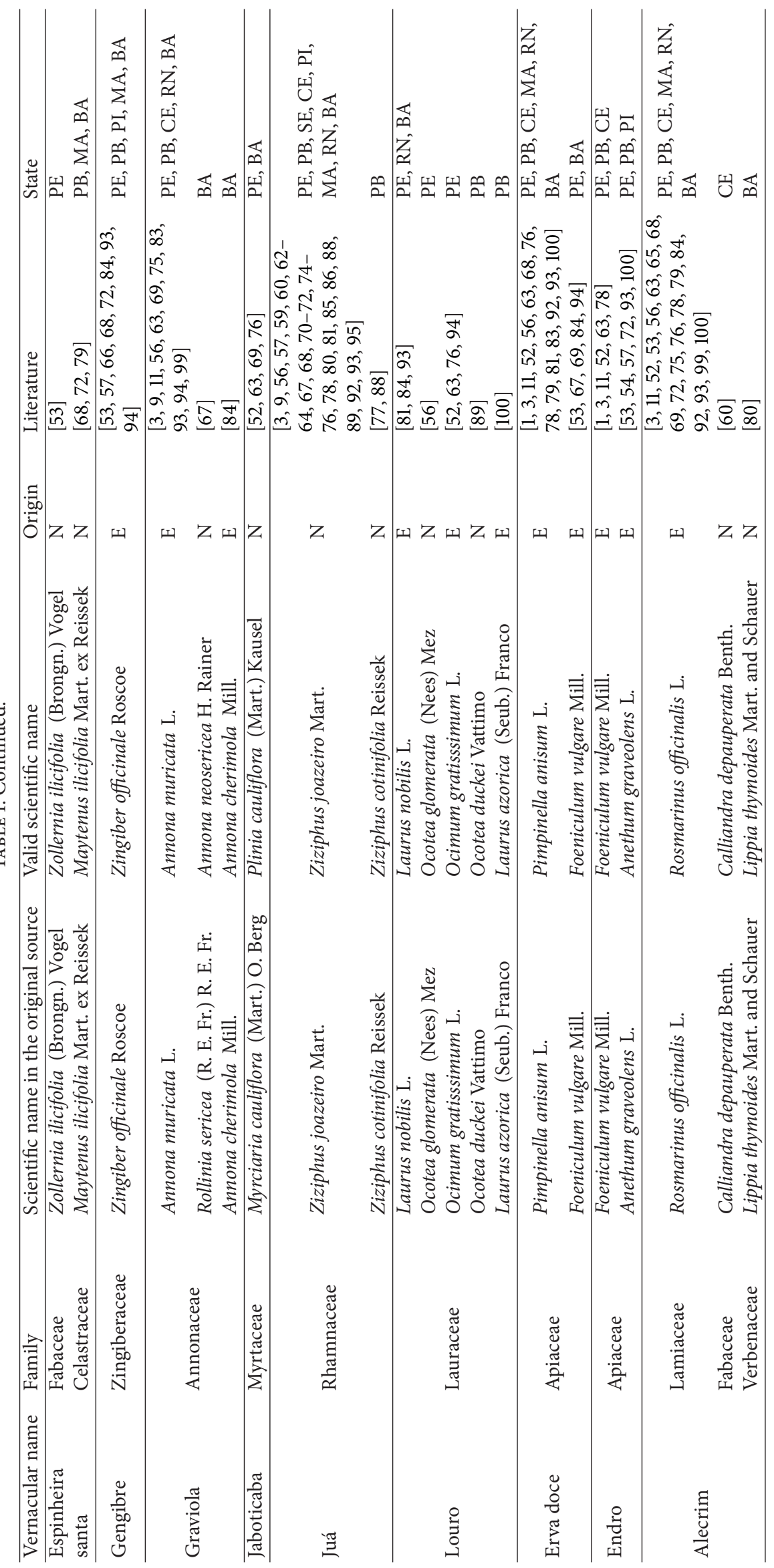




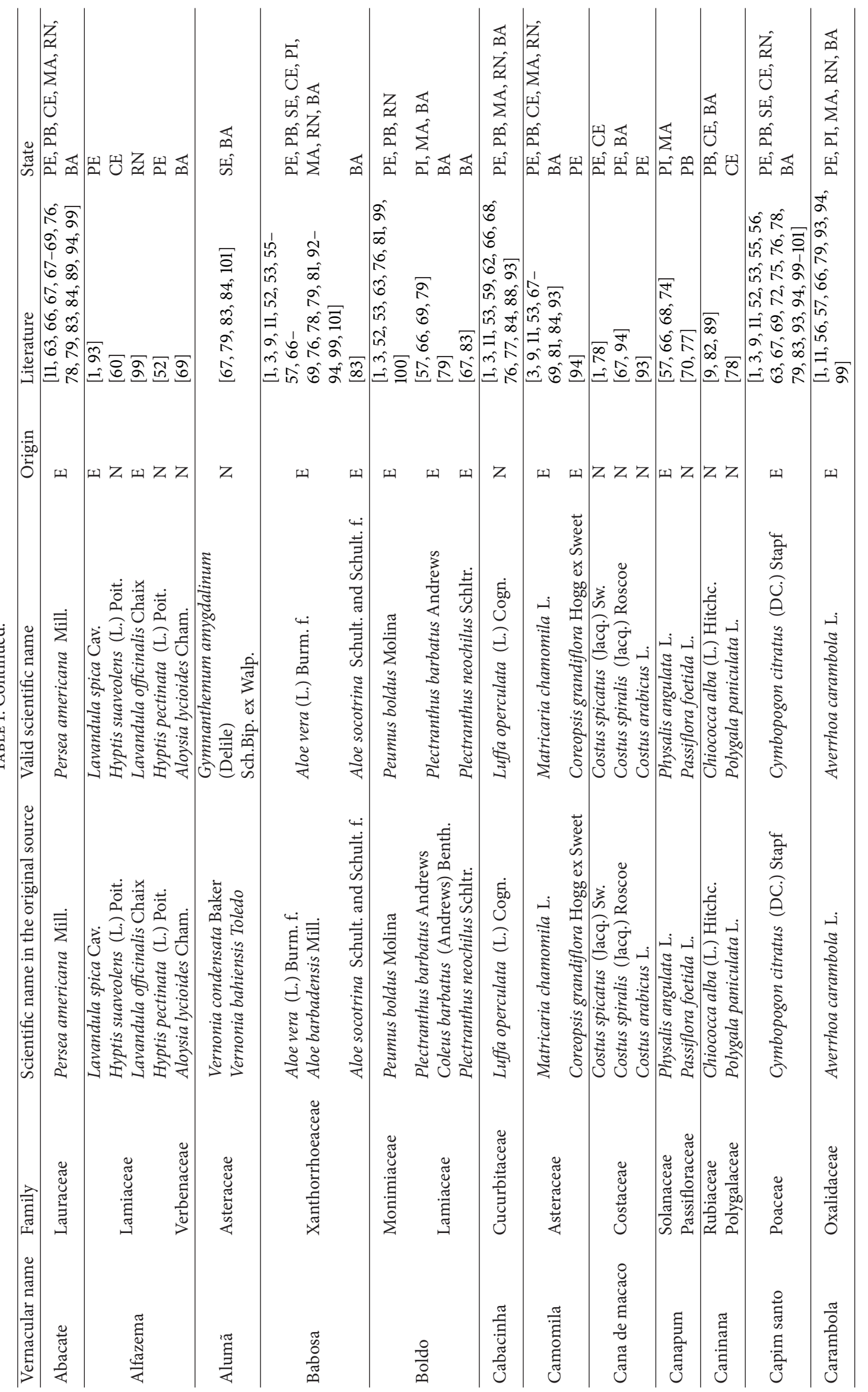




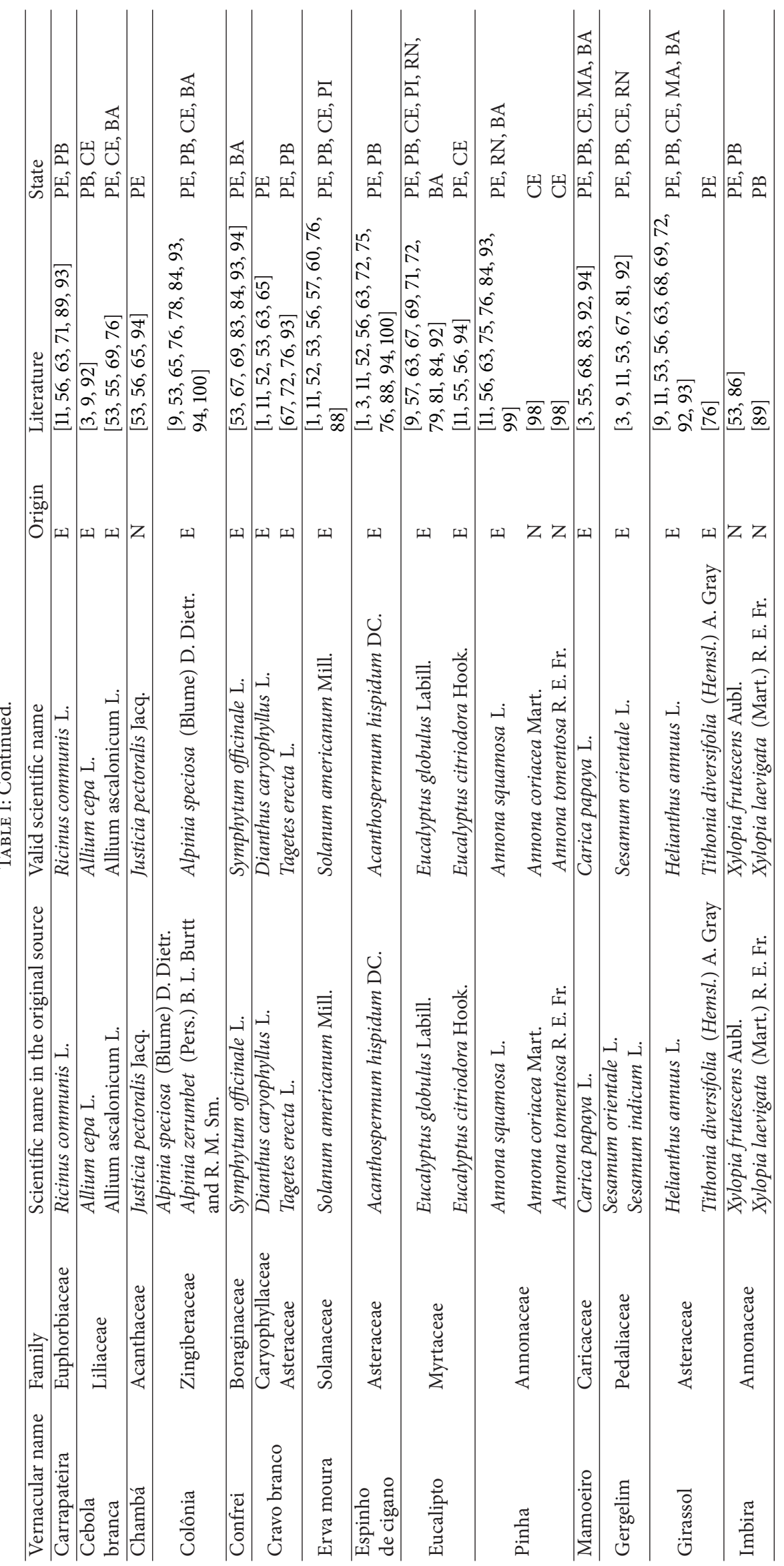




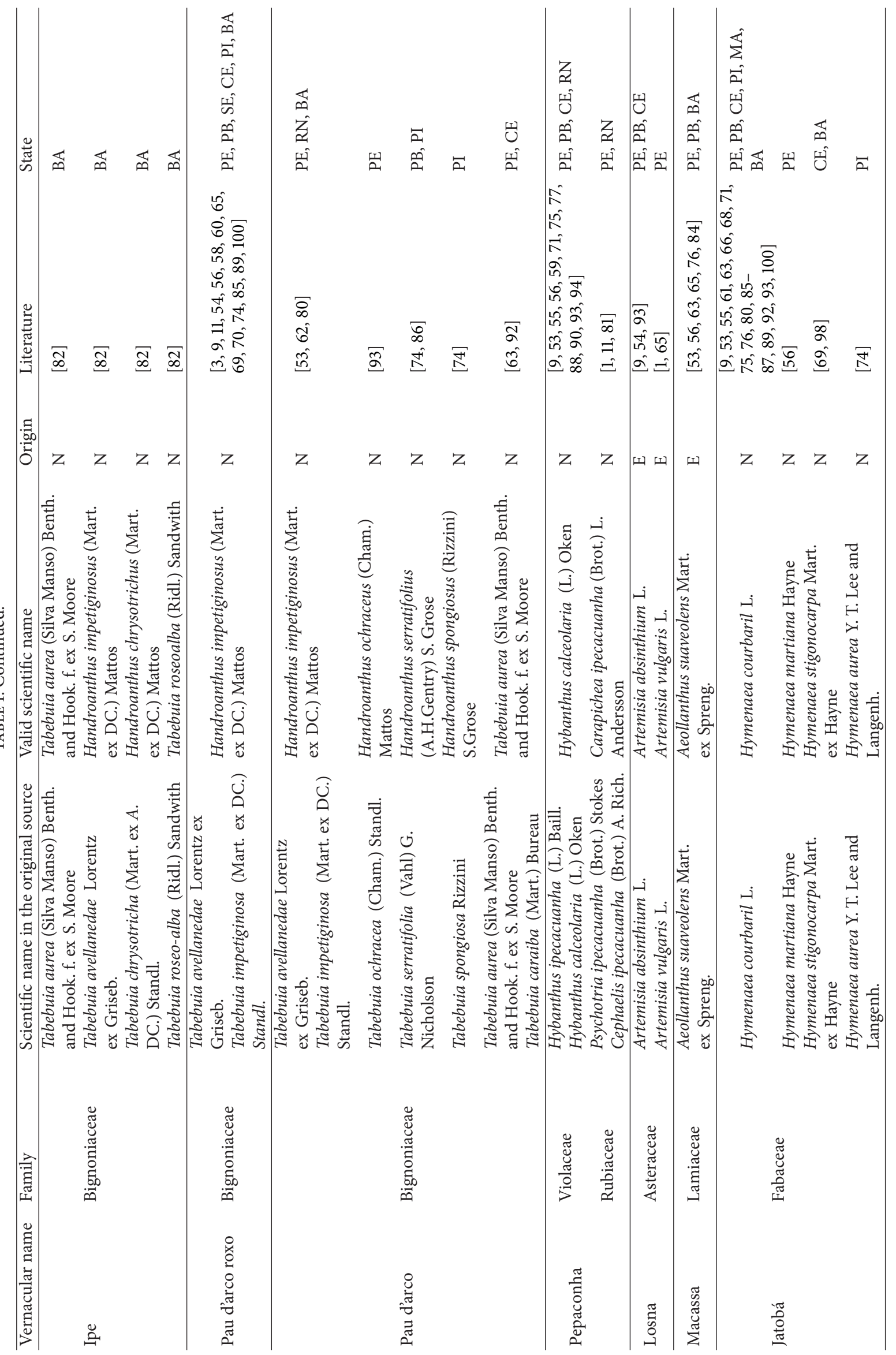




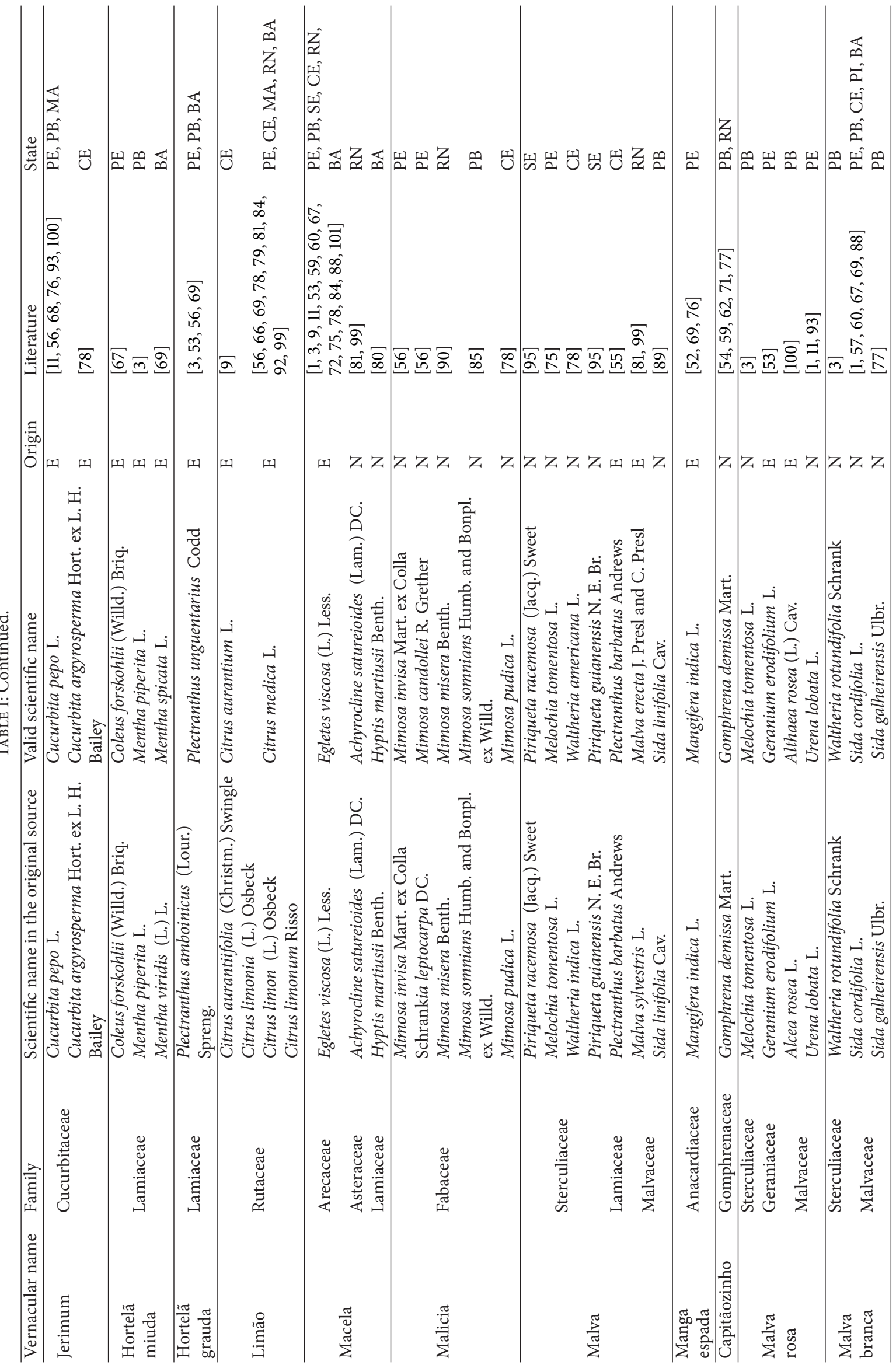




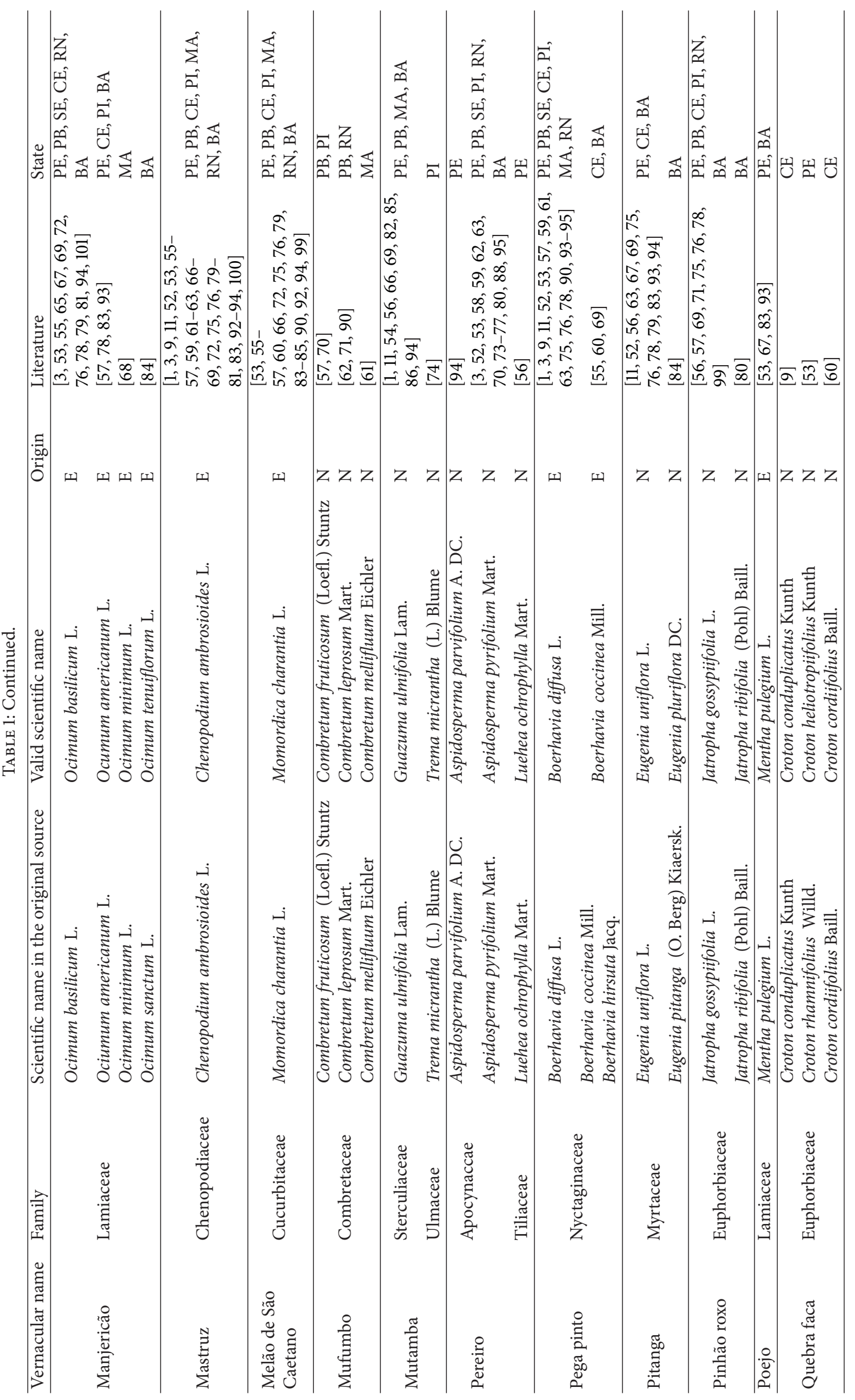




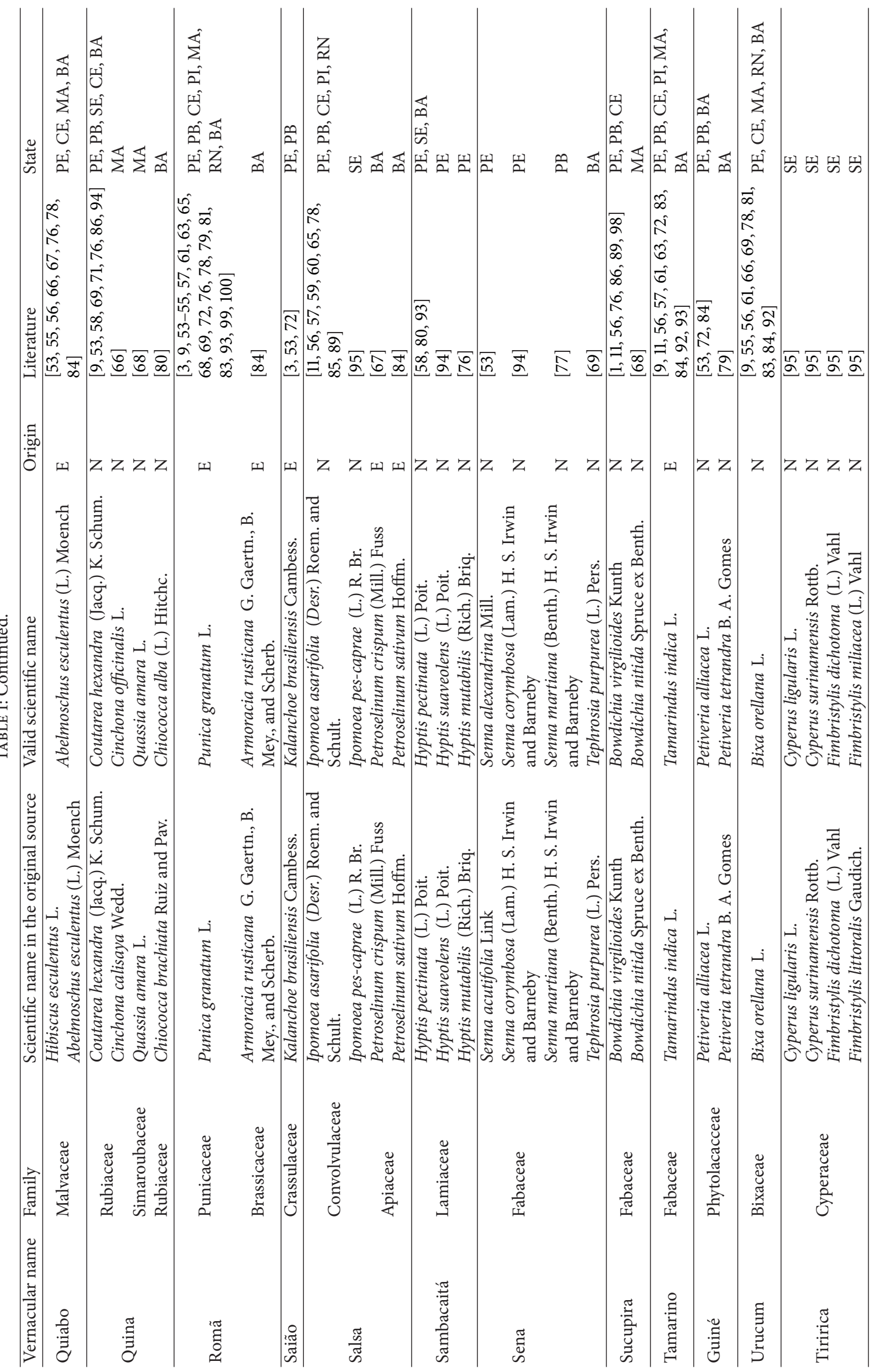




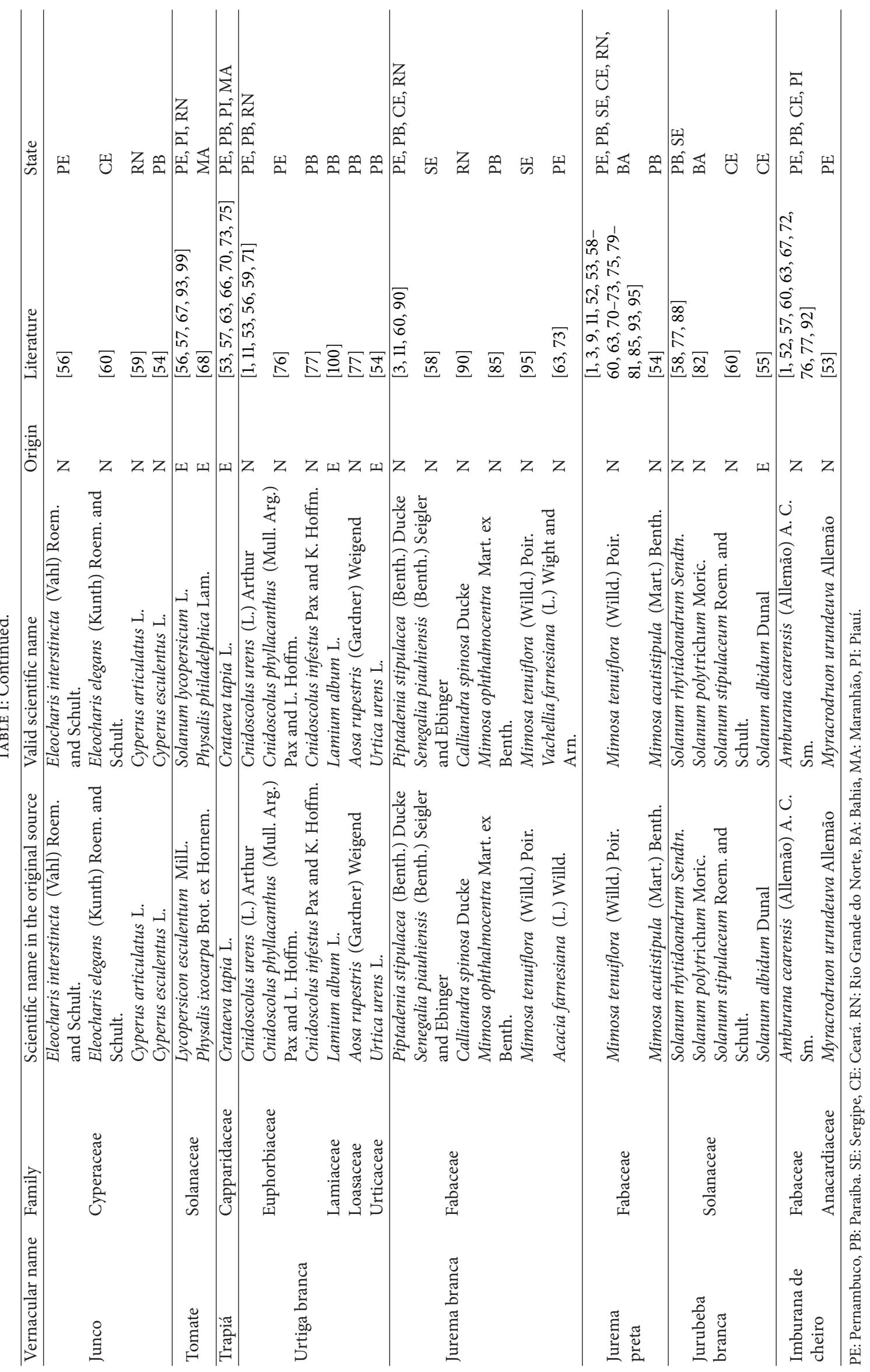


important tool because it might point to the possible patterns of substitution of homonym ethnospecies in a given area. In the case of northeast Brazil, $75 \%$ of the plants traded in regional public markets exhibit correspondence with more than one plant species.

As most (74\%) such species are representative of the native flora, we might infer that the regional markets are largely supplied by natural stocks. Because the demand for medicinal plants is continuously increasing [2], the gradual exhaustion or scarcity of resources might make the substitution of homonym ethnospecies unavoidable and increasingly more frequent, particularly in the large cities where $70 \%$ of the population resides [34] and where access to medicinal plants is primarily mediated by commerce.

Precisely for that reason, it is safe to assert that semantic plurality is manifested most frequently at the public markets of large cities, which are privileged spaces where significant amounts of people, products, and knowledge circulate on a daily basis. Thus, such markets afford an extremely favorable scenario for comparative ethnobotanical studies at a regional level.

In recent years, ethnobotanical research in regional public markets has provided an important platform for conservation studies and biological prospecting. However, the limitations to species identification represent the major hindrance to the growth of research in such locations [6] as well as to the assessment of hidden diversity and events of homonym ethnospecies substitution, as most of the plants are sold in parts or pieces that are sometimes completely uncharacteristic.

For that reason, homonym ethnospecies go easily unnoticed when commercial medicinal species are cataloged, the more so the more remarkable the morphological similarities are. In this regard, $61.3 \%$ of the hidden diversity of the medicinal plants of the northeast region is congeneric, that is, exhibits type 1 underdifferentiation, which denotes phylogenetic proximity and consequently morphological similarity [102]. This similarity makes the understanding of the ethnobotanical data collected at public markets even more difficult.

To prevent this situation, the criteria adopted for the identification of species by some studies conducted in regional public markets are based on the vernacular nomenclature, sometimes as a complementary identifier $[12,103]$ and other times as the primary criterion [6]. In places where the catalog of medicinal plants and the data relative to their biodiversity are comprehensive, common names might possibly be used quite safely. However, this is definitely not the case in Brazil, where the repertoire of medicinal plants in these marketing spaces is largely a hidden diversity.

Additionally, due to the explicit difficulty of recognizing and identifying the plant species in public markets and the progressive increase in the substitution of homonym ethnospecies, the vulnerability of consumers tends to become more serious, and possible risks related to safety and efficacy might be potentiated when one species is indistinctly replaced with another. This phenomenon occurs because most of the Brazilian medicinal plant species have not yet been subjected to appropriate studies that would establish their use in a scientifically safe manner, so to speak, that is, describing their side effects, contraindications, toxicity, and effective therapeutic action.

Because the only plant material available for species identification is that sold at the markets, whereas the harvesting sites are usually inaccessible due to their distance or the unavailability or mistrust of the harvesters-as a large part of harvesting is indiscriminate-the resolution of this impasse necessarily demands more specialized taxonomic procedures, such as micrography and molecular taxonomy.

In this regard, several techniques have been widely applied to the resolution of this type of taxonomic problem [14, $15,104-106]$, to support scientific research and as a tool for the surveillance and control of commercial plant and animal products. Barcoding is one of the most promising among such techniques and has already been applied to the identification of plant species in public markets [107]. This technique consists of the identification of species based on the differentiation of genetic sequences in specific DNA regions [108].

The use of molecular taxonomy might in time become a very important and practical tool for cataloging the hidden diversity in public markets and thus contribute to a better understanding of the biodiversity flow in a given area and, consequently, the frequency with which homonym ethnospecies are being interchangeably used in public markets. A reliable cataloging of this biodiversity affords multiple possibilities for further biological and cultural studies and must be considered as crucial for the advancement of ethnobotanical research.

4.2. Implications for Conservation. From the perspective of conservation at the regional level, one should not ignore the hidden diversity of medicinal plants, as this diversity represents the possible variations in the range of species that are effectively used relative to the multiplicity of homonym ethnospecies and the biological diversity of a given area. On such grounds, one might infer that the larger the number of homonym ethnospecies, the higher the odds that the pressure of use is, or might eventually become, distributed among more than one plant population, as in our study where a significant number of native homonym ethnospecies $(74 \%)$ was found.

When, conversely, the frequency of use predominantly affects one species, the risks are patently greater for the species affected but also for others with the same vernacular name, as due to substitution, those others might become subjected to an intense and fast extractivist pressure that compromises their resilience, particularly in the case of the most vulnerable populations, leading to their collapse.

The species Myracrodruon urundeuva provides a good example of the possible impact of the extractivist pressure on more than one plant population. In this case, another species, Schinus terebinthifolius, which is also native and belongs to the same family, is currently traded under the same generic name ("aroeira"-Brazilian peppertree) in the city of Recife [1]. Therefore, these species are interchangeably used, even though they belong to different genera, as the used parts do not allow for a clear differentiation.

It is possible that such homonym ethnospecies are being overlapped in an unconscious and undocumented manner at 
the points of sale, especially in the case of populations that are no longer easily found in their natural reservoirs and that precisely for that reason are subjected to substitution processes. For example, the case of "espinheira santa" (Maytenus ilicifolia), which following its long-term indiscriminate harvesting became a threatened species [109] and is associated with several substitute species that currently occupy the same semantic-therapeutic niche [110].

This type of approach must be taken into account upon establishing conservation priorities and efficient management strategies, as accurate knowledge of the hidden diversity of medicinal plants and the possibilities for efficient exchanges among homonym ethnospecies might favor a more balanced distribution of the extractivist pressure, thus minimizing its impact, avoiding the collapse of populations and promoting greater resilience.

The applicability of hidden substitutions of species to biological conservation is thus in keeping with explicative models related to the utilitarian redundancy hypothesis [52], according to which a larger number of species within one utilitarian category leads to greater mutual support and protection of the associated species as well as increased resilience.

Thus, we might assert that the phenomenon of the hidden diversity of medicinal plants gives support to utilitarian redundancy as an explanatory model for the pressure of use, as the overlapping species are subsumed under one and the same identity and consequently the same therapeutic indications, as their corresponding practical value is culturally well established.

Because, based on the strength of tradition, the homonym ethnospecies are functional analogs, the remaining task is to distinguish each one of them and establish the level at which the preference for and/or access to each particular species occurs and then to define the degree of utilitarian redundancy, which is also hidden, so to speak. For that purpose, once again the elaboration of a taxonomically reliable record of this biodiversity is required.

Within that context, the assessment of hidden and redundant biodiversity becomes an important predictive ecological tool, as a function of the perfect semantic-therapeutic juxtaposition of the homonym ethnospecies at the regional level. Public policies for the conservation, regulation, control, and use of medicinal plants in Brazil should not ignore the regional level and its implicit cultural and biological richness [111-113]. From this perspective, comparative ethnobotany will become an indispensable tool in decision making and actions aimed at the sustainable use of biodiversity.

4.3. Implications for Bioprospecting. Several studies [114116] have found similar biochemical compositions in related species, which might point to similar uses within the range of applications already well established by tradition. The biochemical constitutions of species in the same family quite commonly include the same pattern of secondary components [114].

Nevertheless, the therapeutic efficacy and the risks associated with the use of the vast majority of species acknowledged as medicinal by the population have not yet been assessed
[117]. With regard to the medicinal species whose safety and efficacy have been demonstrated, ethnobotanical studies that include their hidden diversity might contribute to the identification of more efficacious species as well as of those more promptly available for consumption.

Therefore, the identification of homonym species with similar uses might not only reduce the pressure of use on the natural reservoirs but also allow for easier and more encompassing access for a larger number of people. In this regard, it is worth stressing that to be efficient, public policies addressing access to medicinal plants must take into consideration the natural distribution of the species, when it is spontaneous, and the limits of its ecophysiological tolerance, in the case of cultivated species. The identification of homonym species might represent an alternative in both cases.

Recently, the Brazilian government published a list of 71 medicinal plant species recommended for use by the Unified Health System (Sistema Único de Saúde-SUS) [118]. As a function of the continental size of Brazil and its environmental diversity, the distributions of some of these medicinal species are not homogeneous across all regions. Species typical of the south and southeast regions are hardly found in the north and northeast regions, and vice versa. Therefore, in both cases, there are homonym ethnospecies occupying the same semantic-therapeutic niche of many species in the corresponding region.

The case of Uncaria tomentosa is exemplary. This plant, native to Amazonia (north region), is commonly known as "unha de gato" (cat's claw) and acknowledged for its remarkable anti-inflammatory activity. Although it was included in the SUS list, access to this plant is extremely restricted in other Brazilian regions, which, however, will not prevent the emergence of other types of "cat's claw." There are at least six different species known as "cat's claw" in the northeast region alone, five of which are native and one subspontaneous, corresponding to four different families, thus denoting the generality of the common name and the particularity of the biological expression.

According to Albuquerque and Hanazaki [119] one of the basic rules in biological prospecting is to identify the criteria used by people to select plants for medicinal use. According to those authors, the process underlying such selection might point to more efficacious strategies and shortcuts for the identification of key species relevant to bioprospecting.

A preliminary assessment of the distributions of the ethnospecies in the present study indicated that several species, including exotic ones established centuries ago, have corresponding homonym ethnospecies from the local flora. This is the case for cinnamon, watercress, elder tree, artichoke, clove basil, plum, and rosemary, among others (see Table 1). Such correspondences were also found when medicinal plant species were compared with the names of drugs (generic and trademarks names) with widely acknowledged therapeutic effects, such as Meracilina, penicillin, Novalgina, aspirin, Terramycin, and ampicillin, among others $[9,11,24,93,120$, 121]. In such cases, the species is named after its corresponding drug name, thus representing a flagrant instance of classification based on analogical use. 
Similarly, based on the wide variety and distribution of homonym ethnospecies, we might infer that the development of knowledge at the local level seeks to subsume the available biodiversity under the already established and culturally consolidated semantic-therapeutic patterns. For that reason, when key species with high cultural relevance are absent, the communities tend to opt for species substitutions [52].

As a function of the existence of semantic-therapeutic niches and the impossibility of filling them with traditionally acknowledged species, an analogy-based local process appears to be triggered. According to the available data, several mechanisms of cultural selection are operative in this analogy-based local process, whereby the most fitting pieces of local knowledge become prevalent and amplified across the community, pointing to the locally accessible species, which thus come to be used as corresponding (homonym) ethnospecies. This hypothesis is corroborated by the high frequency of homonym ethnospecies representing the native flora $(73 \%)$.

Comparative ethnobotanical studies of different regions might eventually elucidate the possible role of vernacular names as models for the manifestation of the expression of local biodiversity or the measure and circumstances under which a peculiar regional classification system tends to prevail at the expense of allochthonous and/or general systems. In addition, the identification of the level of semantic similarity of species at the local level might contribute to a better understanding of the process of construction of local/regional knowledge and make the planning of the use, prospection, and conservation of these resources more efficient [122].

\section{Conclusions}

Regardless of being a frequent process, affecting either some or the full set of species of a given region, the substitution of homonym ethnospecies denotes a novel consumption option for a well-established cultural practice involving limited products within a commercial niche consolidated by tradition. For that reason, even where the level, frequency, and circumstances under which such substitutions occur might not be identified in the near future, some relevant questions have already been raised. Such questions, which might contribute to optimizing the use of medicinal plants in a safe and more sustainable manner, include the following. (1) How might the homonym species be alternately used for the same therapeutic action and how efficacious are they? (2) For which homonym ethnospecies might divergent uses, absence, or differences in the level of therapeutic efficacy be currently listed? (3) What are the health risks to people who, either travelling or at their original place of residence, indiscriminately consume different species subsumed under the same common name? (4) What tools might be created to support consumers and researchers in the understanding and interpretation of the semantic plurality associated with medicinal plants? (5) Which bioprospecting actions and management plans have taken the hidden diversity of species at the regional level into consideration?
The fact that a significant percentage of the common names of plants in the Brazilian northeast region exhibits correspondences to multiple species is irrevocably established. A more thorough understanding of the dynamics and dimensions of such semantic-biological variability and the corresponding implications requires the integration of several areas of knowledge, including taxonomy, biochemistry, population ecology, phytosociology, linguistics, and anthropology.

The proportion of species found by ethnospecies (2.78) was significant, although we recognize that a more comprehensive coverage of markets and fairs in the nine northeastern states could lead to an increase of this proportion or even the emergence of new ethnospecies not listed in this survey. To what concerns the low number of respondents committed to the study, in all the six markets visited, it should be clarified that the purpose of the field survey was to catalogue ethnospecies currently marketed in order to support the identification of the corresponding species through the literature search.

\section{Acknowledgments}

The authors thank all of the respondents who participated in the study and the National Council of Scientific and Technological Development (Conselho Nacional de Desenvolvimento Científico e Tecnológico-CNPq) for the scholarships granted to the authors and financial support to UPA ("Edital Universal-2012").

\section{References}

[1] U. P. Albuquerque, J. M. Monteiro, M. A. Ramos, and E. L. C. de Amorim, "Medicinal and magic plants from a public market in northeastern Brazil," Journal of Ethnopharmacology, vol. 110, no. 1, pp. 76-91, 2007.

[2] A. C. Pinto, D. H. Silva, V. S. Bolzani, N. P. Lopes, and R. A. Epifanio, "Produtos naturais: atualidade, desafios e perspectivas," Química Nova, vol. 25, pp. 45-61, 2002.

[3] M. Veeman, "Conociendo los mercados locales y regionales para produtos forestales," in Evaluando la Cosecha Oculta de los Bosques, B. M. Campbell and M. K. Luckert, Eds., pp. 81-116, Nordan-Comunidad, Montevideo, Uruguay, 2002.

[4] A. B. Cunningham, Applied Ethnobotany-People, Wild Plant Use \& Conservation, Earthscan Publications, London, UK, 2001.

[5] E. Hanlidou, R. Karousou, V. Kleftoyanni, and S. Kokkini, “The herbal market of Thessaloniki (N Greece) and its relation to the ethnobotanical tradition," Journal of Ethnopharmacology, vol. 91, no. 2-3, pp. 281-299, 2004.

[6] M. Krog, M. Falcão, and C. S. Olsen, "Medicinal plants markets and trade in Maputo, Mozambique," Forest e Landscape Working Papers 16, Danish Centre for Forest, Landscape and Planning, KVL, 2006.

[7] J. M. Monteiro, M. A. Ramos, E. L. Araújo, E. L. C. Amorim, and U. P. Albuquerque, "Collection and commerce of the Myracrodruon urundeuva Allemão bark in the semi-arid region of Northeastern Brazil," Bioremediation, Biodiversity \& Bioavailability, vol. 5, pp. 100-102, 2011.

[8] C. D. F. C. B. R. Almeida, E. L. C. de Amorim, U. P. de Albuquerque, and M. B. S. Maia, "Medicinal plants popularly used in 
the Xingó region-a semi-arid location in Northeastern Brazil," Journal of Ethnobiology and Ethnomedicine, vol. 2, article 15, pp. $1-9,2006$.

[9] S. L. Cartaxo, M. M. M. Souza, and U. P. de Albuquerque, "Medicinal plants with bioprospecting potential used in semi-arid northeastern Brazil," Journal of Ethnopharmacology, vol. 131, no. 2, pp. 326-342, 2010.

[10] I. G. C. Bieski, F. R. Santos, R. M. de Oliveira et al., "Ethnopharmacology of medicinal plants of the pantanal region (Mato Grosso, Brazil)," Evidence-Based Complementary and Alternative Medicine, vol. 2012, Article ID 272749, 36 pages, 2012.

[11] C. D. F. C. B. R. de Almeida, M. A. Ramos, R. R. V. Silva et al., "Intracultural variation in the knowledge of medicinal plants in an urban-rural community in the Atlantic Forest from Northeastern Brazil," Evidence-Based Complementary and Alternative Medicine, vol. 2012, Article ID 679373, 15 pages, 2012.

[12] E. Lev and Z. Amar, "Ethnopharmacological survey of traditional drugs sold in the Kingdom of Jordan," Journal of Ethnopharmacology, vol. 82, no. 2-3, pp. 131-145, 2002.

[13] M. A. Ramos, U. P. Albuquerque, and E. L. C. Amorim, "O comércio de plantas medicinais em mercados públicos e feiras livres: um estudo de caso," in Tópicos em conservação, etnobotânica e etnofarmacologia de plantas medicinais e mágicas, U. P. Albuquerque, C. F. C. B.R. Almeida, and J. F. A. Marins, Eds., pp. 127-163, NUPEEA/Sociedade Brasileira de Etnoecologia e Etnoecologia, Recife, Brazil, 2005.

[14] S. Molares and A. Ladio, "Métodos micrográficos aplicados à pesquisa etnobotânica," in Métodos e Técnicas na Pesquisa Etnobiológica e Etnoecológica, U. P. Albuquerque, R. F. P. Lucena, and L. V. F. C. Cunha, Eds., pp. 381-399, NUPPEA, Recife, Brazil, 2010.

[15] M. Li, H. Cao, P. P.-H. But, and P.-C. Shaw, "Identification of herbal medicinal materials using DNA barcodes," Journal of Systematics and Evolution, vol. 49, no. 3, pp. 271-283, 2011.

[16] M. L. T. Nguyen, "Cultivated plant collections from markets places," Ethnobotany Research e Applications, vol. 3, pp. 5-15, 2005.

[17] S. Lee, C. Xiao, and S. Pei, "Ethnobotanical survey of medicinal plants at periodic markets of Honghe Prefecture in Yunnan Province, SW China," Journal of Ethnopharmacology, vol. 117, no. 2, pp. 362-377, 2008.

[18] H. C. Conklin, "Lexicographical treatment of folk taxonomies," Journal of American Linguistics, vol. 28, part 4, pp. 119-141, 1962.

[19] D. G. Metzger and G. E. Williams, "Some procedurs and results in the study of native categories: tzeltal 'firewood"' American Anthropologist, vol. 68, pp. 389-407, 1966.

[20] B. Berlin, D. E. Breedlove, and P. H. Raven, "Covert categories and folk taxonomies," American Anthropologist, vol. 70, pp. 290-299, 1968.

[21] T. Hartmann, A Nomenclatura Botânica Borôro, Instituto de Estudos Brasileiros-USP, São Paulo, Brazil, 1967.

[22] B. Berlin, "Folk systematics in relationsystematics in relation to biological classification and nomenclature," Annual Review of Ecology and Systematics, vol. 4, pp. 259-271, 1973.

[23] B. Berlin, Ethnobiological Classification: Principles of Categorization of Plants and Animals in Traditional Societies, Princeton University Press, Princeton, NJ, USA, 1992.

[24] G. S. Vendruscolo, S. M. Eisinger, E. C. Soares, and R. A. Zachia, "Estudo etnobotânico do uso dos recursos vegetais em São João do Polêsine, RS, Brasil, no período de outubro de 1999 a junho de 2073. II-Etnotaxonomia: critérios taxonômicos e sistema de classificação folk," Revista Brasileira de Plantas Medicinais, Botucatu, vol. 7, pp. 44-72, 2005.

[25] P. Hiepko, "Eipo plant nomenclature and classification compared with other folk taxonomic systems," Willdenowia, vol. 36, pp. 447-453, 2006.

[26] M. Haverroth, Etnobotânica, uso e classificação dos vegetais pelos Kaingang, vol. 3 of Séries de Estudos e Debates, NUPEEA, Recife, Brazil, 2007.

[27] K. Khasbagan and S. Soyolt, "Indigenous knowledge for plant species diversity: a case study of wild plants' folk names used by the Mongolians in Ejina desert area, Inner Mongolia, P. R. China," Journal of Ethnobiology and Ethnomedicine, vol. 4, article 2, 2008.

[28] M. A. Signorini, M. Piredda, and P. Bruschi, "Plants and traditional knowledge: an ethnobotanical investigation on Monte Ortobene (Nuoro, Sardinia)," Journal of Ethnobiology and Ethnomedicine, vol. 5, article 6, 2009.

[29] P. Burke, Hibridismo Cultural, Unisinos, São Leopoldo, Brazil, 2003.

[30] I. Nesheim, S. S. Dhillion, and K. A. Stølen, "What happens to traditional knowledge and use of natural resources when people migrate?" Human Ecology, vol. 34, no. 1, pp. 99-131, 2006.

[31] International Institute for Enviromental and Development (IIED), The Hidden Haverst: The Value of Wild Resources in Agricultural Systems, IIED, London, UK, 1995.

[32] International Institute for Enviromental and Development (IIED), "Valuing the hidden haverst: methodological approaches for local level economic analysis of wild resources," Research series, vol. 3, no. 4, Sustainable Agriculture and Environmental Economics, IIED, London, UK, 1997.

[33] E. Elisabetsky and L. Wannmacher, "The status of ethnopharmacology in Brazil," Journal of Ethnopharmacology, vol. 38, no. 2-3, pp. 137-143, 1993.

[34] "IBGE Instituto Brasileiro de Geografia e Estatística," http:// www.ibge.gov.br/.

[35] I. R. Leal, M. Tabarelli, and J. M. C. Silva, Ecologia e conservação da Caatinga, Editora Universitária, Universidade Federal de Pernambuco, Recife, Brazil, 2003.

[36] D. Prado, "As caatingas da América do Sul," in Ecologia e conservação da Caatinga, I. R. Leal, M. Tabarelli, and J. M. C. Silva, Eds., pp. 3-73, Editora Universitária, Universidade Federal de Pernambuco, Recife, Brazil, 2003.

[37] A. M. Giulietti, A. L. Bocage Neta, A. A. J. F. Castro et al., "Diagnóstico da vegetação nativa do bioma Caatinga," in Biodiversidade da Caatinga: áreas e ações prioritárias para a conservação, J. M. C. Silva, M. Tabarelli, M. T. Fonseca, and L. V. Lins, Eds., pp. 48-90, Ministério do Meio Ambiente, Brasília, Brazil, 2004.

[38] N. Myers, R. A. Mittermeler, C. G. Mittermeler, G. A. B. da Fonseca, and J. Kent, "Biodiversity hotspots for conservation priorities," Nature, vol. 403, no. 6772, pp. 853-858, 2000.

[39] C. Galindo-Leal and I. G. Câmara, "Atlantic forest hotspots status: an overview," in The Atlantic Forest of South America: Biodiversity Status, Threats, and Outlook, C. Galindo-Leal and I. G. Câmara, Eds., pp. 3-11, Center for Applied Biodiversity Science e Island Press, Washington, DC, USA, 2003.

[40] C. T. Rizzini, Tratado de Fitogeografia de Brasil: Aspectos ecológicos, sociológicos e florísticos, Âmbito Cultural Edições Ltda, Rio de Janeiro, Brazil, 1997.

[41] A. A. J. F. Castro and F. R. Martins, "Cerrados do Brasil e do Nordeste: caracterização, área de ocupação e considerações sobre a sua fitodiversidade," Pesquisa em Foco, vol. 7, pp. 147-178, 1999. 
[42] R. T. Pennington, M. Lavin, D. E. Prado, C. A. Pendry, S. K. Pell, and C. A. Butterworth, "Historical climate change and speciation: Neotropical seasonally dry forest plants show patterns of both Tertiary and Quaternary diversification," Philosophical Transactions of the Royal Society B, vol. 359, no. 1443, pp. 515537, 2004.

[43] M. Tabarelli and A. M. M. Santos, "Uma breve descrição sobre a história natural dos Brejos Nordestinos," in Brejos de Altitude em Pernambuco e Paraíba, História Natural, Ecologia e Conservação, K. C. Porto, J. J. P. Cabral, and M. Tabarelli, Eds., vol. 9 of série Biodiversidade, pp. 17-24, Ministério do Meio Ambiente, Brasília, Brazil, 2004.

[44] M. Tabarelli, S. R. R. Pinto, and I. R. Leal, "Floresta Atlântica nordestina: fragmentação, degeneração e conservação," Ciência Hoje, vol. 44, pp. 36-41, 2009.

[45] I. R. Leal, J. M. Silva, M. Tabarelli, and T. E. Lacher Jr., "Mudando o curso da conservação da biodiversidade na Caatinga do Nordeste do Brasil," in Megadiversidade, vol. 1, pp. 139-146, Conservação Internacional do Brasil, Belo Horizonte, Brazil, 2005.

[46] G. Freyre, Nordeste, Record, Rio de Janeiro, Brazil, 1989.

[47] D. Ribeiro, O Povo Brasileiro: A Formação e o Sentido de Brasil, Companhia das Letras, São Paulo, Brazil, 2nd edition, 1995.

[48] G. J. Martin, Ethnobotany, A Methods Manual, Chapman \& Hall, London, UK, 1995.

[49] Jardim Botânico do Rio de Janeiro, "Lista de Espécies da Flora do Brasil 2012," http://floradobrasil.jbrj.gov.br/.

[50] "Missouri Botanical Garden (MOBOT)-W3 TROPICOS," http://www.mobot.org/.

[51] R. R. Sokal and F. G. Rholf, Biometry, W. H. Freeman and Company, New York, NY, USA, 1995.

[52] U. P. D. Albuquerque and R. F. D. Oliveira, "Is the use-impact on native caatinga species in Brazil reduced by the high species richness of medicinal plants?" Journal of Ethnopharmacology, vol. 113, no. 1, pp. 156-170, 2007.

[53] J. M. Monteiro, M. A. Ramos, E. D. L. Araújo, E. L. C. Amorim, and U. P. Albuquerque, "Dynamics of medicinal plants knowledge and commerce in an urban ecosystem (Pernambuco, Northeast Brazil)," Environmental Monitoring and Assessment, vol. 178, no. 1-4, pp. 179-202, 2011.

[54] C. A. Agra, "Identificação das plantas medicinais indicadas pelos raizeiros e utilizados pelas mulheres no combate a enfermidades do aparelho geniturinário da cidade de campina grande-PB," BIOFAR, vol. 73, no. 73, 2007.

[55] S. M. Morais, J. D. P. Dantas, A. R. A. Silva, and E. F. Mangalhães, "Plantas medicinais usadas pelos índios Tapebas do Ceará," Revista Brasileira de Farmacognosia, vol. 15, no. 2, pp. 169-177, 2005.

[56] A. J. R. Silva and L. H. C. Andrade, "Etnobotânica Nordestina: estudo comparativo da relação entre comunidades e vegetação na Zona do Litoral- Mata do Estado de Pernambuco, Brasil," Acta Botanica Brasílica, vol. 19, no. 1, pp. 45-60, 2005.

[57] F. C. S. Oliveira, R. F. M. Barros, and J. M. Moita Neto, "Plantas medicinais utilizadas em comunidades rurais de Oeiras, semiárido piauiense," Revista Brasileira de Plantas Medicinais, vol. 12, no. 3, pp. 282-373, 2010.

[58] W. J. Machado, A. P. N. Prata, and A. A. Mello, "Floristic composition in areas of caatinga and brejo de altitude in sergipe state, Brazil," Check List, vol. 8, pp. 1089-1173, 2012.

[59] A. A. Roque, R. M. Rocha, and M. I. B. Loiola, "Uso e diversidade de plantas medicinais da Caatinga na comunidade rural de
Laginhas, município de Caicó, Rio Grande do Norte (Nordeste do Brasil)," Revista Brasileira de Plantas Medicinais, vol. 12, no. 1, pp. 31-42, 2010.

[60] J. B. L. P. Medeiros, Zoneamento Fito-Ecológico da Estação Ecológica de Aiuaba: Uma Contribuição à Educação Ambiental $e$ à Pesquisa Científica, [M.S. thesis], Universidade Federal do Ceará, Fortaleza, Brazil, 2004.

[61] J. M. Nascimento and G. M. Conceiçao, "Plantas Medicinais e indicações Terapêuticas da Comunidade Quilombola Olho D’água do Raposo, Caxias, Maranhão, Brasil," Revista de Biologia e Farmácia, vol. 6, no. 2, pp. 138-151, 2011.

[62] M. S. Silva, A. R. Antoniolli, J. S. Batista, and C. N. Mota, "Plantas medicinais usadas nos distúrbios do trato gastrintestinal no povoado Colônia Treze Lagarto, SE, Brasil," Acta Botanica Brasílica, vol. 20, no. 4, pp. 815-829, 2006.

[63] U. P. de Albuquerque, T. A. de Sousa Araújo, M. A. Ramos et al., "How ethnobotany can aid biodiversity conservation: reflections on investigations in the semi-arid region of NE Brazil," Biodiversity and Conservation, vol. 18, no. 1, pp. 127-150, 2009.

[64] R. L. C. de Oliveira, E. M. F. Lins Neto, E. L. Araújo, and U. P. Albuquerque, "Conservation priorities and population structure of woody medicinal plants in an area of caatinga vegetation (Pernambuco State, NE Brazil)," Environmental Monitoring and Assessment, vol. 132, no. 1-3, pp. 189-206, 2007.

[65] U. P. Albuquerque, "Plantas Medicinais e Mágicas Comercializadas Nos Mercados Públicos do Recife-PE," Ciência e Trópico, vol. 25, no. 1, pp. 7-15, 1997.

[66] R. Monteles and C. U. B. Pinheiro, "Plantas medicinais em um quilombo maranhense: uma perspectiva etnobotânica," Revista de Biologia e Ciências da Terra, vol. 7, pp. 38-48, 2007.

[67] F. D. S. Silva, M. A. Ramos, N. Hanazaki, and U. P. de Albuquerque, "Dynamics of traditional knowledge of medicinal plants in a rural community in the Brazilian semi-arid region," Brazilian Journal of Pharmacognosy, vol. 21, no. 3, pp. 382-391, 2011.

[68] I. M. Madaleno, "Plantas da medicina popular de São Luís, Brasil," Boletim do Museu Paraense Emilio Goeldi. Ciencias Humanas, vol. 6, no. 2, pp. 273-286, 2011.

[69] N. C. Barboza da Silva, A. C. Delfino Regis, M. A. Esquibel, J. Espírito Santo Santos, and M. Z. Almeida, "Uso de plantas medicinais na comunidade quilombola da Barra II-Bahia, Brasil," Boletín Latinoamericano y del Caribe de Plantas Medicinales y Aromáticas, vol. 11, no. 5, pp. 435-453, 2012.

[70] A. P. Leite, K. M. Pedrosa, C. M. Lucena, T. K. N. Carvalho, L. P. Felix, and R. F. P. Lucena, "Uso e conhecimento de espécies vegetais úteis em uma comunidade rural no vale do Piancó (Paraíba, Nordeste, Brasil)," Biofar: Revista de Biologia e Farmácia, pp. 133-157, 2012.

[71] M. G. V. Marinho, C. C. Silva, and L. H. C. Andrade, "Levantamento etnobotânico de plantas medicinais em área de caatinga no município de São José de Espinharas, Paraíba, Brasil," Revista Brasileira de Plantas Medicinais, vol. 13, no. 2, pp. 170-182, 2011.

[72] M. M. Araujo, Estudo etnobotânico das plantas utilizadas como medicinais no assentamento Santo Antônio, Cajazeiras, PB, Brasil [M.S. thesis], Universidade Federal de Campina Grande, Paraíba, Brazil, 2009.

[73] R. F. P. Lucena, U. P. Albuquerque, J. M. Monteiro, C. D. F. B. R. Almeida, A. T. N. Florentino, and J. S. F. Ferraz, "Useful plants of the semi-arid northeastern region of Brazil-a look at their conservation and sustainable use," Environmental Monitoring and Assessment, vol. 125, no. 1-3, pp. 281-290, 2007. 
[74] J. R. Lemos, “Composição florística do Parque Nacional Serra da Capivara, Piauí, Brasil," Rodriguesia, vol. 55, no. 85, pp. 5566, 2004.

[75] U. P. Albuquerque and L. H. C. Andrade, "Conhecimento botânico tradicional e conservação em uma área de caatinga no estado de Pernambuco," Acta Botanica Brasilica, vol. 16, no. 3, pp. 273-285, 2002.

[76] U. P. de Albuquerque, V. A. da Silva, M. D. C. Cabral, N. Leal Alencar, and L. D. H. C. Andrade, "Comparisons between the use of medicinal plants in indigenous and rural caatinga (dryland) communities in NE Brazil," Boletin Latinoamericano y del Caribe de Plantas Medicinales y Aromáticas, vol. 7, no. 3, pp. 156-170, 2008.

[77] M. F. Agra, G. S. Baracho, K. Nurit, I. J. L. D. Basílio, V. P. M. Coelho, and D. A. Barbosa, "Sinopse da flora medicinal do Cariri Paraibano," Oecologia Brasiliensis, pp. 323-330, 2007.

[78] A. L. Balcazar, Hipótese da aparência na dinâmica do uso de plantas medicinais na floresta nacional do Araripe (Ceará, Noredeste do Brasil) [M.S. thesis], Universidade Federal Rural de Pernambuco, Recife, Brazil, 2012.

[79] J. A. Castro, B. P. Brasileiro, D. H. Lyra, D. de Almeida Pereira, J. L. Chaves, and C. L. F. Amaral, "Ethnobotanical study of traditional uses of medicinal plants: the flora of caatinga in the community of Cravolândia-BA, Brazil," Journal of Medicinal Plant Research, vol. 5, no. 10, pp. 1905-1917, 2011.

[80] V. S. Almeida and F. P. S. F. Bandeira, "O significado cultural do uso de plantas da caatinga pelos quilombolas do Raso da Catarina, município de Jeremoabo, Bahia, Brasil," Rodriguesia, vol. 61, pp. 195-209, 2010.

[81] A. M. N. M. Guerra, M. F. Pessoa, C. S. M. Souza, and P. B. Maracajá, "Utilização de plantas medicinais pela comunidade rural Moacir Lucena, Apodi-RN," Bioscience Journal, vol. 26, pp. 442450, 2010.

[82] R. C. Brito, Estudo Preliminar de Avaliação Ambiental Estratégica do Plano Diretor-Campus Ondina, Universidade Federal da Bahia, Salvador, Brazil, 2008.

[83] L. C. B. Costa, R. C. T. Moreira, R. C. S. Costa, and E. A. R. M. Lucena, "Abordagem etnobotânica acerca do uso de plantas medicinais na Vila Cachoeira, Ilhéus, Bahia, Brasil," Acta Farmaceutica Bonaerense, vol. 21, pp. 205-211, 2002.

[84] M. Z. Almeida, Plantas Medicinais, EDUFBA, Salvador, Brazil, 2011.

[85] D. B. O. Abreu, R. B. Oliveira Filho, C. F. A. Vasconcelos Netos, C. M. Lucena, L. P. Felix, and R. F. P. Lucena, "Classificação etnobotânica por uma comunidade rural em um brejo de altitude no Nordeste do Brasil," Biofar: Revista de Biologia e Farmácia, vol. 6, pp. 55-74, 2011.

[86] F. X. Oliveira, L. A. Andrade, and L. P. Félix, "Comparações florísticas e estruturais entre comunidades de Floresta Ombrófila Aberta com diferentes idades, no Município de Areia, PB, Brasil," Acta Botanica Brasílica, vol. 20, pp. 861-873, 2006.

[87] M. Q. Matos and J. M. Felili, "Florística, fitossociologia e diversidade da vegetação arbórea nas matas de galeria do Parque Nacional de Sete Cidades (PNSC), Piauí, Brasil," Acta Botancia Brasilica, vol. 24, no. 2, pp. 483-496, 2010.

[88] M. F. Agra, G. S. Baracho, K. Nurit, I. J. L. D. Basílio, and V. P. M. Coelho, "Medicinal and poisonous diversity of the flora of "Cariri Paraibano", Brazil," Journal of Ethnopharmacology, vol. 111, no. 2, pp. 383-395, 2007.

[89] M. S. Pereira and R. R. N. Alves, "Composição florística de um remanescente de Mata Atlântica na Área de Proteção Ambiental
Barra do Rio Mamanguape, Paraíba, Brasil," Revista de Biologia e Ciências da Terra, vol. 6, pp. 357-366, 2006.

[90] M. I. B. Loiola, G. B. D. C. Paterno, J. A. Diniz, J. F. Calado, and A. C. P. de OLiveira, "Leguminosae and its potencial of use in the rural communities of São miguel do gostoso-RN," Revista Caatinga, vol. 23, no. 3, pp. 59-70, 2010.

[91] P. M. S. Silva, D. O. Brandão, T. P. Chaves et al., "Study bioprospecting of medicinal plant extracts of the semi-arid northeast: contribution to the control of oral microorganisms," EvidenceBased Complementary and Alternative Medicine, vol. 2012, Article ID 681207, 6 pages, 2012.

[92] I. G. Oliveira, L. S. Cartaxo, and M. A. P. da Silva, "Plantas medicinais utilizadas na farmacopéia popular em Crato, Juazeiro e Barbalha (Ceará, Brasil)," Revista Brasileira de Biociências, vol. 5, no. 1, pp. 189-191, 2007.

[93] S. A. Texeira and J. I. M. Melo, "Plantas medicinais utilizadas no município de Jupi, Pernambuco, Brasil," Iheringiano, vol. 61, no. 1-2, pp. 5-11, 2006.

[94] G. L. Oliveira, Etnobotânica nordestina: plantas medicinais utilizadas na comunidade Muribeca (Jaboatão dos Guararapes, PE) [M.S. thesis], Universidade Federal de Pernambuco, Recife, Brazil, 2007.

[95] A. C. C. Silva, Monumento Natural Grota do Angico, Sergipe, Brasil: Florística, estrutura da vegetação e conservação [M.S. thesis], Universidade Federal de Sergipe, São Cristóvão, Brazil, 2010.

[96] C. S. Santos, Diagnóstico da flora apícola para sustentabildade da apicultura no Estado de Sergipe [M.S. thesis], Universidade Federal de Sergipe, São Cristóvão, Brazil, 2009.

[97] M. L. R. A. Omena, Estudo etnofarmacológico de plantas com ação no sistema nervoso central: perspectiva de sustentabilidade em Umbuzeiro do Matuto-Porto da Folha/SE [M.S. thesis], Universidade Federal de Sergipe, São Cristóvão, Brazil, 2003.

[98] I. R. Costa, F. S. Araújo, and L. W. Lima-Verde, "Flora e aspectos auto-ecológicos de um encrave de cerrado na chapada do Araripe, Nordeste do Brasil," Acta Botanica Brasilica, vol. 18, no. 4, pp. 759-770, 2004.

[99] V. M. Morais, Etnobotânica nos quintais da comunidade de Abderramant em Caraúbas-RN [Ph.D. thesis], Universidade Federal Rural do Semi-àrido, Rio Grande do Norte, Brazil.

[100] G. P. S. Sales, H. N. Albuquerque, and M. L. F. Cavalcanti, "Estudo do uso de plantas medicinais pela comunidade quilombola Senhor do Bonfim, Areia (PB)," Revista de Biologia e Ciências da Terra, vol. 1, pp. 55-66, 2004.

[101] T. S. Silva and E. M. X. Freire, "Abordagem etnobotânica sobre plantas medicinais citadas por populações do entorno de uma unidade de conservação da caatinga do Rio Grande do Norte, Brasil," Revista Brasileira de Plantas Medicinais, vol. 12, no. 4, pp. 427-435, 2010.

[102] W. S. Judd, C. S. Campbell, E. A. Kellog, P. F. Stevens, and M. J. Donoghue, Sistemática Vegetal: Um Enfoque Filogenético, Artmed, Porto Alegre, Brazil, 2009.

[103] J. Botha, E. T. F. Witkowski, and C. M. A. Shackleton, "Market profiles and trade in medicinal plants in the Lowveld, South Africa," Environmental Conservation, vol. 31, no. 1, pp. 38-46, 2004.

[104] M. G. Lusa and C. Bona, "Caracterização morfoanatômica e histoquímica de Cuphea carthagenensis (Jacq.) J.f. Macbr. (Lythraceae)," Acta Botanica Brasilica, vol. 25, no. 2, pp. 517-527, 2011.

[105] C.-L. Lee and S.-Y. Chen, "Classification of leaf images," International Journal of Imaging Systems and Technology, vol. 16, no. 1, pp. 15-23, 2006. 
[106] Q. D. Wheeler, "Taxonomic triage and the poverty of phylogeny," Philosophical Transactions of the Royal Society B, vol. 359, no. 1444, pp. 571-583, 2004.

[107] E. Mati and H. de Boer, "Ethnobotany and trade of medicinal plants in the Qaysari Market, Kurdish Autonomous Region, Iraq," Journal of Ethnopharmacology, vol. 133, no. 2, pp. 490-510, 2011.

[108] P. D. N. Hebert, A. Cywinska, S. L. Ball, and J. R. de Waard, "Biological identifications through DNA barcodes," Proceedings of the Royal Society B, vol. 270, no. 1512, pp. 313-321, 2003.

[109] M. P. Mariot and R. L. Barbieri, "Divergência genética entre acessos de espinheira-santa (Maytenus ilicifolia Mart. ex Reissek e M. aquifolium Mart.) com base em caracteres morfológicos e fisiológicos," A Revista Brasileira de Plantas Medicinais, vol. 12, no. 3, pp. 243-249, 2010.

[110] S. Coulaud-Cunha, R. S. Oliveira, and W. Waissmmann, "Venda livre de Sorocea bonplandii Bailon como Espinheira-Santa no Município do Rio de Janeiro-RJ," Revista Brasileira de Farmacognosia, vol. 4, supplement 1, pp. 51-53, 2004.

[111] A. C. S. Diegues and R. S. V. Arruda, Saberes tradicionais e biodiversidade no Brasil, Biodiversidade 4, Ministério do Meio Ambiente, USP, São Paulo, Brazil, 2001.

[112] A. Begossi, N. Hanazaki, and J. Y. Tamashiro, "Medicinal plants in the Atlantic Forest (Brazil): knowledge, use, and conservation," Human Ecology, vol. 30, no. 3, pp. 281-299, 2002.

[113] M. Tabarelli and J. M. C. Silva, “Áreas e ações prioritárias para a conservação, utilização sustentável e repartição de benefícios do bioma Caatinga," in Biodiversidade, conservação e uso sustentável da flora do Brasil, E. L. Araújo, A. N. Moura, E. V. S. B. Sampaio, L. M. S. Gestinari, and J. M. T. Carneiro, Eds., vol. 1, pp. 47-52, Imprensa Universitária da UFRPE, Recife, Brazil, 2002.

[114] D. E. Moerman and G. F. Estabrook, "Native Americans' choice of species for medicinal use is dependent on plant family: confirmation with meta-significance analysis," Journal of Ethnopharmacology, vol. 87, no. 1, pp. 51-59, 2003.

[115] A. Smelcerovic and M. Spiteller, "Phytochemical analysis of nine Hypericum L. species from Serbia and the F.Y.R. Macedonia," Pharmazie, vol. 61, no. 3, pp. 251-252, 2006.

[116] M. L. Silva and V. Cechinel Filho, "Plantas do gênero Bauhinia: composição química e potencial farmacológico," Química Nova, vol. 25, pp. 449-454, 2002.

[117] M. P. Guerra and R. O. Nodari, "Biodiversidade: aspectos biológicos, geográficos, legais e éticos," in Farmacognisia: da planta ao medicamento, C. M. Simões et al., Ed., Editora da UFRGS; Editora da UFSC, Florianópolis, Brazil, 2004.

[118] Brasil, Relação Nacional de Plantas Medicinais de Interesse ao SUS, DAF/SCTIE/MS-RENISUS, Ministério da Saúde, Brasília, Brazil, 2009, http://portal.saude.gov.br/portal/arquivos/pdf/RENISUS.pdf.

[119] U. P. Albuquerque and N. Hanazaki, "As pesquisas etnodirigidas na descoberta de novos fármacos de interesse médico e farmacêutico: fragilidades e pespectivas," Revista Brasileira de Farmacognosia, vol. 16, pp. 678-689, 2006.

[120] G. S. Vendruscolo and L. A. Mentz, "Levantamento etnobotânico das plantas utilizadas como medicinais por moradores do bairro Ponta Grossa, Porto Alegre, Rio Grande do Sul, Brasil," Iheringia, Série Botânica, vol. 61, no. 1-2, pp. 83-103, 2006.

[121] C. D. F. C. B. R. de Almeida, M. A. Ramos, E. L. C. de Amorim, and U. P. de Albuquerque, "A comparison of knowledge about medicinal plants for three rural communities in the semi-arid region of northeast of Brazil," Journal of Ethnopharmacology, vol. 127 , no. 3, pp. 674-684, 2010.
[122] A. C. S. Diegues, Etnoconservação-Novos Rumos para a Conservação da Natureza, Nupaub e HUCITEC, São Paulo, Brazil, 2000. 


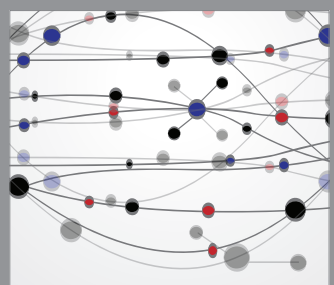

The Scientific World Journal
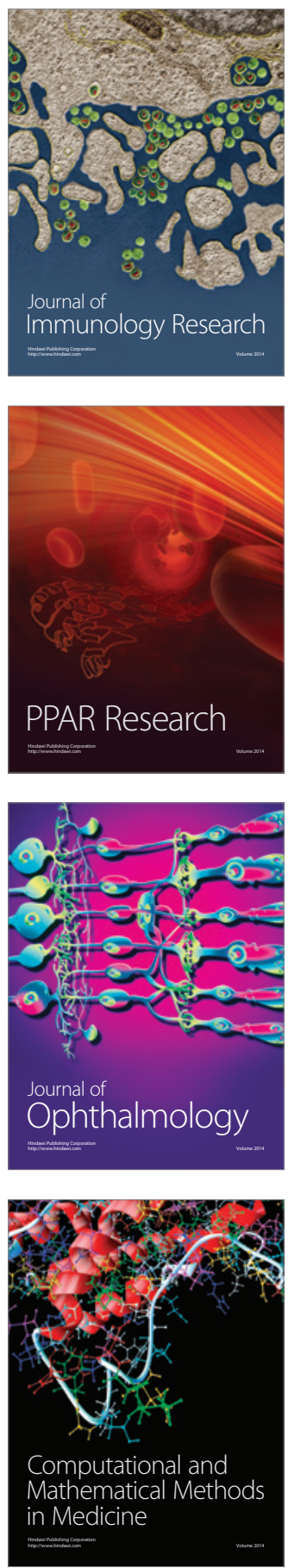

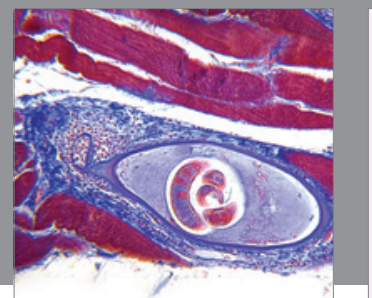

Gastroenterology

Research and Practice
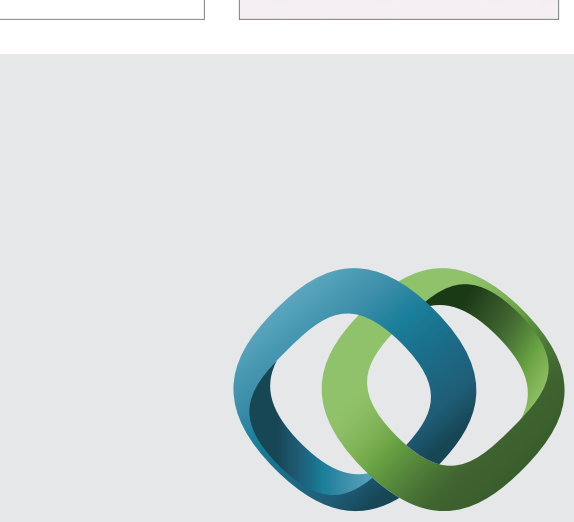

\section{Hindawi}

Submit your manuscripts at

http://www.hindawi.com
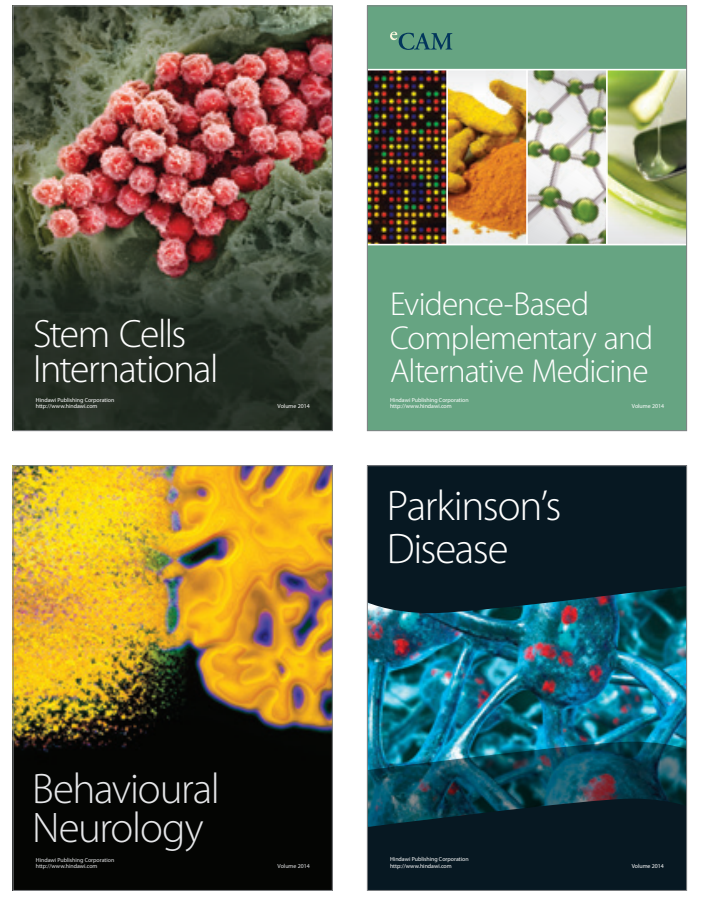
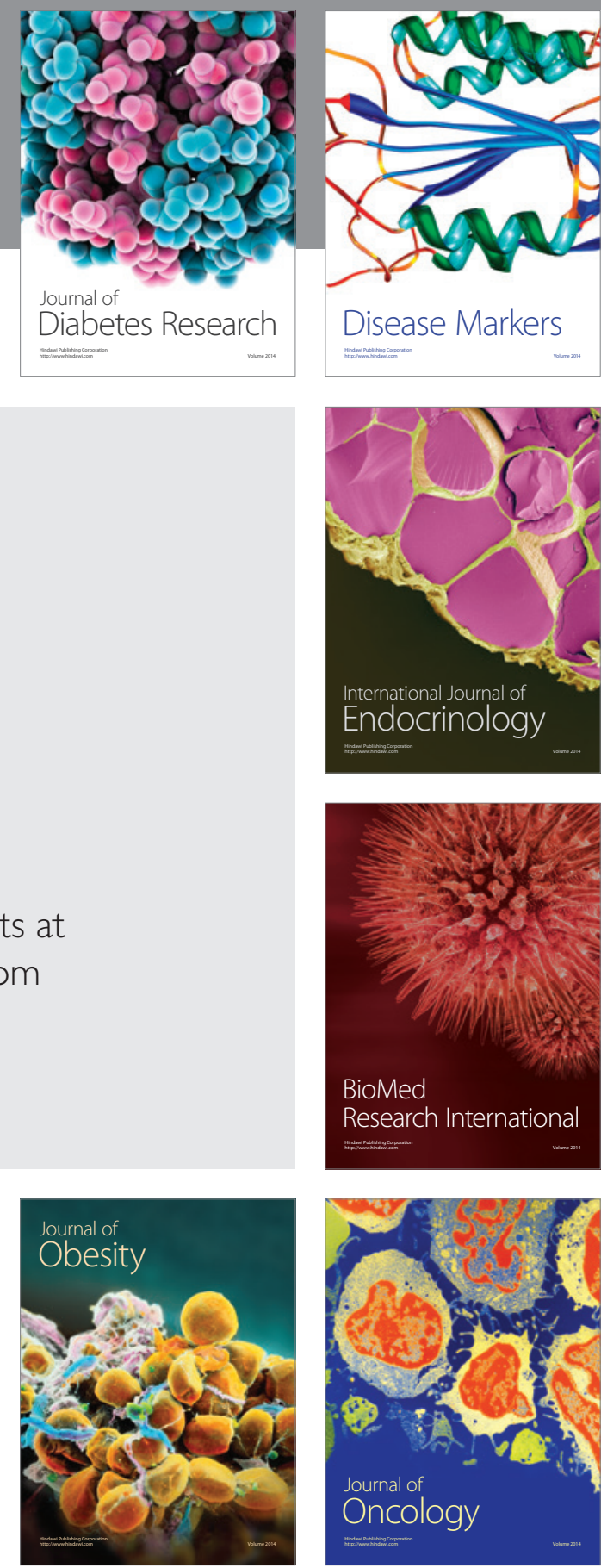

Disease Markers
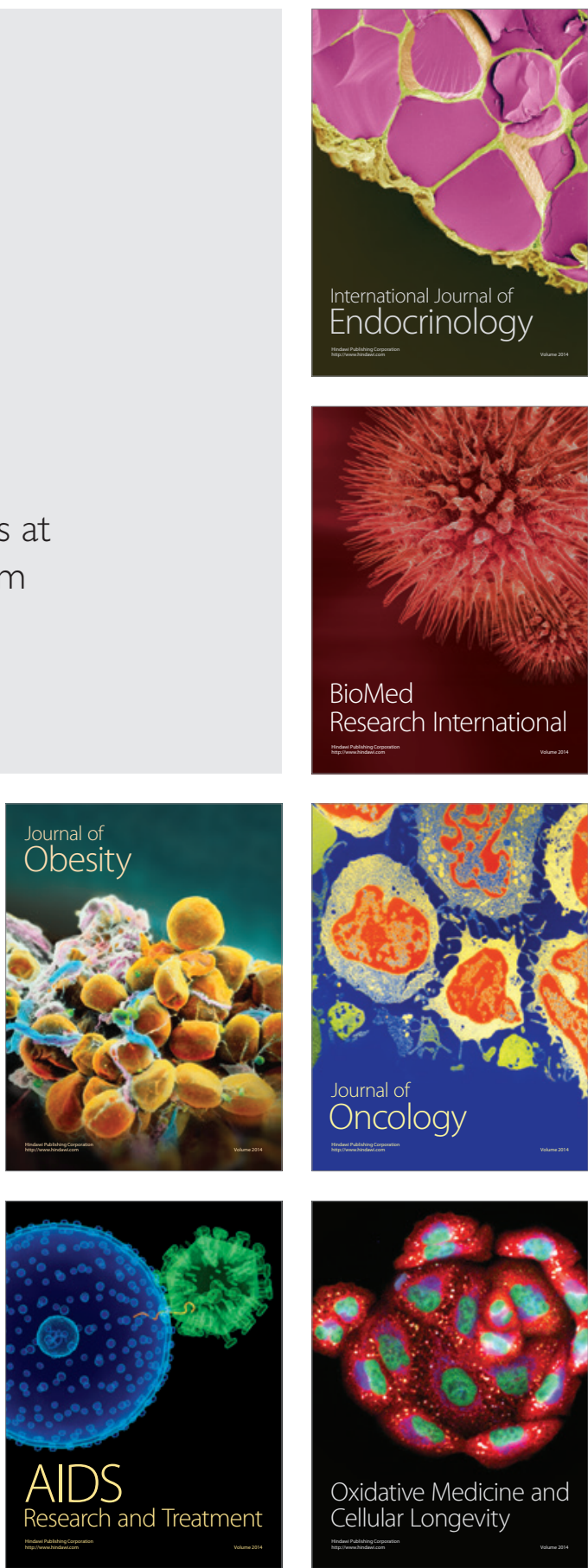